\title{
Interannual sea ice thickness variability in the Bay of Bothnia
}

\author{
Iina Ronkainen ${ }^{1}$, Jonni Lehtiranta ${ }^{1}$, Mikko Lensu ${ }^{1}$, Eero Rinne ${ }^{1}$, Jari Haapala ${ }^{1}$, and Christian Haas ${ }^{2}$ \\ ${ }^{1}$ Finnish Meteorological Institute, 00560 Helsinki, Finland \\ ${ }^{2}$ Alfred Wegener Institute, 27570 Bremerhaven, Germany
}

Correspondence: Iina Ronkainen (iina.ronkainen@ @mi.fi)

Received: 30 April 2018 - Discussion started: 15 May 2018

Revised: 3 October 2018 - Accepted: 9 October 2018 - Published: 8 November 2018

\begin{abstract}
While variations of Baltic Sea ice extent and thickness have been extensively studied, there is little information about drift ice thickness, distribution, and its variability. In our study, we quantify the interannual variability of sea ice thickness in the Bay of Bothnia during the years 2003-2016. We use various different data sets: official ice charts, drilling data from the regular monitoring stations in the coastal fast ice zone, and helicopter and shipborne electromagnetic soundings. We analyze the different data sets and compare them to each other to characterize the interannual variability, to discuss the ratio of level and deformed ice, and to derive ice thickness distributions in the drift ice zone. In the fast ice zone the average ice thickness is $0.58 \pm 0.13 \mathrm{~m}$. Deformed ice increases the variability of ice conditions in the drift ice zone, where the average ice thickness is $0.92 \pm 0.33 \mathrm{~m}$. On average, the fraction of deformed ice is $50 \%$ to $70 \%$ of the total volume. In heavily ridged ice regions near the coast, mean ice thickness is approximately half a meter thicker than that of pure thermodynamically grown fast ice. Drift ice exhibits larger interannual variability than fast ice.
\end{abstract}

\section{Introduction}

The Baltic Sea belongs to the seasonal sea ice zone, extending from 54 to $66^{\circ} \mathrm{N}$, and has a total area of $422000 \mathrm{~km}^{2}$. According to the classification of the Finnish Ice Service, the Baltic ice season is mild when the ice extent is below $115000 \mathrm{~km}^{2}$, severe when the extent is above $230000 \mathrm{~km}^{2}$, and extremely severe when it is above $345000 \mathrm{~km}^{2}$. The last occurrence of almost complete ice cover was in 1987 (96\%; Vihma and Haapala, 2009). Other major seas that are seasonally ice covered include the Sea of Okhotsk and Bohai Sea in
Asia and the Hudson Bay and Gulf of St. Lawrence in North America.

The Bay of Bothnia is the northernmost basin of the Baltic Sea north of the sound of Quark at $63.5^{\circ} \mathrm{N}$ (Fig. 1). It is a semi-enclosed basin with a length of about $300 \mathrm{~km}$, width of $100-150 \mathrm{~km}$, and an area of approximately $36000 \mathrm{~km}^{2}$. The average depth is $41 \mathrm{~m}$ and maximum depth $146 \mathrm{~m}$ (Leppäranta and Myrberg, 2009). During the last 100 years the Bay of Bothnia has always frozen completely over except in the extremely mild winters of 2014-2015 and most probably also in 1929-1930 (Uotila et al., 2015). During winter the bay's shores are covered by fast ice, its width varying with the sheltering of the archipelago. In more open areas its boundary roughly follows the $10 \mathrm{~m}$ depth contour. In the drift ice zone, the flux of the ice trough in the $25 \mathrm{~km}$ wide passage of Quark is small and has only a minor effect on the ice mass balance of the basin, which is mostly determined by the thermodynamic and dynamic processes within the basin itself; i.e., according to our understanding the exchange of ice with the Gulf of Bothnia in the south is negligible.

In the fast ice zone, ice grows thermodynamically because the ice is attached to the coast and does not move. Along the coastline of the Bay of Bothnia there is a large area where the shallowness of the sea allows fast ice to form every winter. Depending on the ice thickness, the boundary of the fast ice zone is where the depth is $5-15 \mathrm{~m}$. On the contrary, in the drift ice zone, ice floes move with the currents and winds and pile up to ridges. Ridges can grow up to several meters. When ice is piling up in one region, open water forms in another, and favorable conditions for the formation of new ice occur. Thus, the growth of ice in the drift ice zone consists of thermodynamic and dynamic processes (Leppäranta and Myrberg, 2009). 
Forcings in the thermodynamic and dynamic processes are different. Sensible and long-wave radiation fluxes and snow accumulation are the main factors to drive thermodynamic growth. The thicker the ice grows the more it insulates itself and grows slower. Snow layers on the ice also act as insulation. On the other hand, if there is a lot of snow on the ice, seawater floods on the ice and can form snow ice on top of the ice cover. Dynamic processes are more complicated than thermodynamic ones. Ice motion is driven by winds and currents and can form rafted, ridged, or brash ice (Leppäranta and Myrberg, 2009).

The fast ice zone of the Bay of Bothnia consists of level ice types which grow purely thermodynamically in more sheltered areas. In the beginning of the ice season in fall, there is fast ice in more sheltered areas. During the winter the fast ice zone expands to shallow drift ice areas, where depth is under $10 \mathrm{~m}$. As the fast ice boundary advances offshore during the ice season, the ice types in more exposed areas may drift and experience deformations. This initial thickness variation is smoothed by thermodynamic growth after the ice stabilizes into fast ice. The drift ice zone is a mixture of level and deformed ice types of different thicknesses and typically has a high ridge density. In heavily ridged areas the largest ridges may reach $20 \mathrm{~m}$ below the surface (Palosuo, 1975). The variability of thermal and dynamic forcing leads to large ice thickness variations both in space and time. In addition there are large coastal gradients generated by coastal process cycles like lead opening, refreezing, and deformation (cf. Pärn and Haapala, 2011; Oikkonen et al., 2016).

Sea ice conditions are typically characterized by ice extent, ice thickness, and ice concentration. Baltic ice charts, providing the ice covered area, have been drawn and the phases of the ice season have been followed systematically since 1915. In the Bay of Bothnia there is a more than 100 year long record of drill-hole measurements and of the dates of freeze up and melt from fixed sites. These have been restricted to the fast ice zone. The thickness of level ice types within the drift ice zone is measured or estimated by icebreakers and reported in the ice charts. These values usually seek to characterize the regional level ice thickness for navigation purposes and have limited accuracy. The complete thickness distribution including level and deformed ice has been studied in two types of individual campaigns: from thickness profiles determined by air and shipborne electromagnetic (EM) sounding since 2003 and indirectly from surface profiles since 1988. These data sets do not cover all years, and the individual campaigns do not cover all parts of the Bay of Bothnia. Also, most of the campaigns have been conducted during the midwinter period from February to March, when the ice may still grow and deform further.

Previous studies of the long-term thickness statistics in the Bay of Bothnia have mostly concentrated on annual maximum level ice thickness in the fast ice zone, especially at Kemi which is close to northernmost end of the basin. Leppäranta and Seinä (1985) determined that there was a statisti- cally significant increasing trend in the maximum annual ice thickness at Kemi from 1912 to 1984 . An increasing trend at Kemi was also recorded in later research from 1912 to 1996 (Jevrejeva et al., 2004) and from 1912 to 2011 (Haapala et al., 2015). The mean maximum annual ice thickness at Kemi from 1912 to 2011 is $73 \mathrm{~cm}$ (Haapala et al., 2015).

In the Bay of Bothnia or even in the Baltic Sea, the interannual changes of drift ice thickness have not been studied before. However, many similar studies have been carried out in the Arctic (Meier et al., 2014) and Antarctic. Airborne EM measurements have been used to determine the reduction in ice thickness near the North Pole during 1991-2007 (Haas et al., 2008), to describe the ice thickness in the Northwest Passage (Haas and Howell, 2015), to estimate ice thickness in a pan-Arctic survey (Haas et al., 2010), and to study ice thickness in the Barents Sea (King et al., 2017). Air and shipborne EM measurements have also been carried out in the Antarctic (Haas, 1998; Weissling et al., 2011; Sugimoto et al., 2016). In seasonal seas, ice thickness has been studied, for example, by upward-looking sonar in the Bohai Sea (Su et al., 2013).

The interannual variability of ice extent generally follows the variations in large-scale atmospheric forcing. In the Baltic Sea the North Atlantic Oscillation (NAO) index is a good proxy for this. Strong westerlies blow over the north Atlantic during positive phases of the NAO index, and conditions over the Baltic Sea are mild and moist. During negative NAO phases, westerlies weaken or are blocked totally, and then winters are more severe. Vihma and Haapala (2009) found that during the winters with a strongly positive NAO index the average of maximum annual ice extent in the Baltic Sea was $121000 \mathrm{~km}^{2}$, whereas during the winters with a strongly negative NAO index, it was $259000 \mathrm{~km}^{2}$. However, for example in 1985-1986, the NAO index was negative only in February, while the seasonal NAO index was positive, and the ice extent was very large in that winter. The influence of NAO index to ice thickness has not been studied in the northern Baltic Sea. Specifically, it is not known how the different wind and temperature statistics, characteristic of a positive and negative NAO index, combine to generate a specific ratio of level and deformed ice types in the ice volume budget.

It is important to investigate sea ice changes in the seasonal sea ice zone for two reasons. First, for hundreds of years, there has been interest in sea ice observations to help navigation. Second, interest in climate change is increasing, and sea ice changes strongly reflect the changing climate.

The average ice season in the Bay of Bothnia lasts from November to May (Haapala et al., 2015). Thus, sea ice is an essential factor in the area. Every winter, both Finnish and Swedish icebreakers assist ships on route to harbors in Bay of Bothnia. Winter navigation has continuously increased, and more information on the ice conditions is required. Ridged areas can especially cause major problems to ships. Milder winters are not necessarily easier for navigation. The ice thickness distribution and the amount of ridges affect navigation more. 
In this study we are using all available measurements from various helicopter and shipborne EM field campaigns to determine the variability of sea ice thickness in the Bay of Bothnia in more detail. The aim of our study is to combine and compare these data with existing in situ drilling data from the fast ice zone and ice chart thickness information. Despite the fact that the EM measurements have not been conducted along the same tracks or over the same areas in every year, we presume that this unique data set is sufficiently extensive to reveal the main features of the regional and interannual variability of ice thickness. The data have been used in developing satellite sea ice retrieval methods (Gegiuc et al., 2018) and the validation of numerical models (Löptien et al., 2013; Pemberton et al., 2017), but geophysical analysis of the data has only been conducted by Haas (2004a), who concluded that level ice thickness was close to the values reported in ice charts, but the actual mean ice thickness is much larger due to ridged ice. In this paper, we estimate for the first time, the variability of ice thickness in the drift ice region and generate ice thickness distributions for individual years as well as discuss their interannual variability. We also provide an estimate of the climatologically averaged thickness distribution for the Bay of Bothnia.

\section{Data and methods}

Ice thickness can be measured by several methods: visual observations from ships; drilling; electromagnetic induction (EM) sounding from sledges, ships, or aircraft; upwardlooking sonar from moorings or submarines; and satellite altimetry (Eicken et al., 2009; Haas, 2017). We use several different data sets to get the best possible overview of the variability of sea ice thickness. Ice charts divide the ice cover into regions representing ice fields with different characteristics and age, and the thickness values seek to represent the typical thickness of level ice in each region. Drilling data at fixed observation stations are accurate and long term but have been made only in the fast ice zone. The EM data resolve the detailed ice thickness distributions in the drift ice zone, but study regions and times have so far been limited to a few campaigns during the period of maximum ice extent.

To define the sea area, we used the following locations as the definition of the southern boundary of the Bay of Bothnia (Leppäranta and Myrberg, 2009): Iskmo, Raippaluoto, Björkö, Lappören, Valassaaret, and Hadding Peninsula (see Fig. 1). The area of the Bay of Bothnia is $36260 \mathrm{~km}^{2}$. We mark the winters according to the year in the spring. For example 2003 means the winter of 2002-2003.

\subsection{Ice charts}

During the ice season, ice charts are published daily by the ice service of the Finnish Meteorological Institute. At the very beginning and end of the season, the frequency of

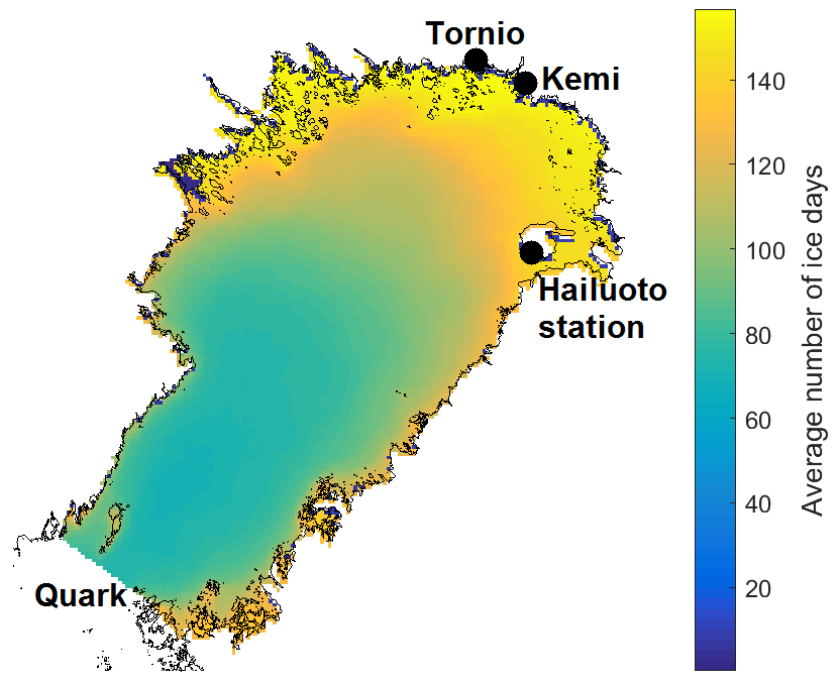

Figure 1. The average number of ice days per season determined from ice charts and the location of places mentioned in text. Hailuoto station is the location of the ice drilling station at Hailuoto island.

the charts is usually reduced to biweekly maps. Apart from graphic charts, gridded versions with different resolutions are prepared for various purposes. These include grids for concentration, average thickness, maximum thickness, minimum thickness, deformation numeral (degree of ice ridging), and sea surface temperature. The deformation numerals from 0 to 5 denote level ice, rafted ice, slightly ridged ice, ridged ice, heavily ridged ice, and brash barrier. The graphic charts, on the other hand, represent these types with qualitative symbols only.

The main information sources for the charts are satellite images for ice existence and concentration and in situ measurements and visual observations for ice thickness. The thickness values are based on observations made by the crew of icebreakers and, for nearshore fast ice, at fixed stations. The station values are from drilling, while the icebreaker values are estimates from tilting floes during transit in ice and occasional drillings. The thickness values refer to ice types with a flat surface that can be level ice or rafted ice and seek to characterize the regional conditions. The deformation numerals are based mostly on visual icebreaker observations and seek to be a regionally representative description of the conditions from the point of view of navigational difficulty. No rules for estimating total thickness from ice chart thicknesses and the numerals have been established yet, although a clear correlation exists (Gegiuc et al., 2018).

We calculated the average annual statistics for the Bay of Bothnia using gridded ice charts for the 14 season period of 2003-2016. The grid resolution is $1 / 60$ of a degree in the $\mathrm{N}-\mathrm{S}$ direction and $2 / 60$ of a degree the in $\mathrm{E}-\mathrm{W}$ direction. True grid cell areas were used in calculations, and the effect of land point occurrence in the cells was estimated. The 
common period was chosen to be from 1 October to 31 May. For ice-free days, grids with zero values for ice parameters were used. During the very early phases of the ice season, the charts are biweekly and the latest ice chart was assumed to stay valid during the intermediate days. The same was assumed for the few gaps, usually 1 day in duration, during the main ice season. As these assumptions were mainly done for the very early phases of the ice season, when there is not much ice yet, this barely affects our results.

\subsection{EM data}

One of the most efficient ways to measure sea ice thickness over a large area is electromagnetic induction (EM) sounding. EM sounding allows sea ice thickness measurements from a moving platform. Here we use data from a helicoptertowed EM-bird (HEM, Haas et al., 2009) and shipborne Geonics EM-31. EM instruments induce electric eddy currents in conductive layers in the underground and measure the amplitude and phase of the resulting EM fields. From these, the distance to the different layers can be accurately determined (e.g., Haas et al., 1997). With sea ice thickness measurements, the seawater is assumed to be a half-space of constant, known electrical conductivity underneath the resistive sea ice, and the distance to the ice-water interface can be retrieved with a single measurement frequency. EM measurements in the brackish water of the Baltic Sea depend on in situ measurements of local seawater conductivity. When the EM instrument is suspended from a moving vehicle, the distance to sea ice is not fixed and needs to be measured separately by a laser distance sensor and subtracted from the EMretrieved distance to seawater to get the ice thickness (Haas et al., 2009).

A single-frequency EM device cannot differentiate between snow and ice because they are both highly resistive. Therefore snow thickness is always included in the measured total ice thickness. Similarly, conductive layers like flooded snow on ice or porous ridge keels cannot be distinguished and will lead to underestimates of total ice thickness.

The EM thickness measurements are weighted averages over the instrument footprint. The footprint size depends on the distance between the instrument and the ice-water interface. EM measurements are affected by smoothing over the footprint, i.e., the area from which an EM device receives most of the return signal. It is roughly $5 \mathrm{~m}$ for the shipborne EM-31 and between 3 and 4 times the flying altitude for HEM measurements. Typical altitude for the HEMbird is about $15 \mathrm{~m}$, resulting in a footprint size on the order of $50 \mathrm{~m}$. Thickness variations on scales smaller than the footprint are smoothed, and therefore ridge keel depths are underestimated, or closely arranged keels may join into one feature. This especially affects the tail part of the thickness histogram. Additionally the instrument sensitivity decreases with increasing distance to seawater, and in general thicknesses greater than $4 \mathrm{~m}$ are seen as unreliable. Usually the
EM thicknesses are accepted at their face value and interpreted as average thickness over footprint.

Results of ice thickness surveys are commonly displayed as thickness distributions (histograms). Caution is due when interpreting and comparing thickness histograms and their mean values. First, thickness refers to the distance between the ice surface and the approximate ice-water interface. Considerations involving ice mass balance, especially the transition of level ice types to ridged ice, must take into account the relative void content (porosity), which can be 20-40\% for the unconsolidated part of ridge keels (Leppäranta, 2005). We estimate that we underestimate ridge keel volume by $4 \%$ due to this effect, assuming an exponential probability distribution model for keel depths.

To present the distribution of ice thickness we computed normalized frequency histograms with a bin width of $0.1 \mathrm{~m}$ from EM data. In some years the spatial density of EM surveys is much higher in certain areas than elsewhere, especially close to the land base of EM flights. To avoid bias from the dominance of such areas, we first calculated histograms in $1 \times 1$ square nautical mile $\left(\mathrm{NM}^{2}\right)$ grid cells in the regions of the surveys and then averaged all histograms from the grid cells to one histogram. In addition to histograms pertaining to each campaign, a histogram for all 5 years of helicopter EM data was constructed by averaging the annual histograms.

We extended the range of the histograms to negative thicknesses to show the accuracy of the EM measurements. Negative thicknesses can result over open water or thin ice if the true ice thickness is less than the accuracy of $\pm 0.1 \mathrm{~m}$ of the EM measurements. Then the subtraction of the laser derived height above the snow surface from the EM-derived distance to the ice-water interface can yield negative values. However, the fact that hardly any measurements have thicknesses below $0 \mathrm{~m}$ confirms the accuracy of the measurements.

\subsubsection{Helicopter EM data}

HEM surveys were carried out in the Bay of Bothnia in years 2003, 2004, 2005, 2007, and 2011 (Table 1). The flights were mostly made during a short time period from the end of February to the first half of March, i.e., potentially before the ice reached its maximum annual thickness. The measurements are from different routes in different years. Thus, a comparison of the measurements in different years is not unproblematic.

Haas (2006) has shown that ice thicknesses are overestimated in brackish water shallower than 15 to $20 \mathrm{~m}$ with the signal frequency of $4 \mathrm{kHz}$ used here. This is due to induction in the seafloor with its lower conductivity compared to seawater. To prevent this error, we masked the data when water depth was less than $15 \mathrm{~m}$.

The first HEM measurements in the Baltic Sea were conducted within the EU-IRIS project in 2003 (Haas, 2003). The aim of the measurements was to test the method over the brackish water of the Baltic and to obtain data on sea ice 
Table 1. Summary of helicopter and ship-based EM data used in this paper.

\begin{tabular}{llll}
\hline Year & Dates & Instrument & Campaign \\
\hline 2003 & 20-21 February & Helicopter-towed EM-bird & IRIS \\
2004 & 5 February-17 March & Helicopter-towed EM-bird & IRIS \\
2005 & 10-16 March & Helicopter-towed EM-bird & CryoVEx \\
2007 & 11-14 March & Helicopter-towed EM-bird & POL-ICE \\
2011 & 2-7 March & Helicopter-towed EM-bird & SafeWin \\
2012 & 21-22 March & Shipborne Geonics EM-31 & SA Agulhas II ice test \\
2016 & 1-10 March & Shipborne Geonics EM-31 & Aranda sea ice cruise 2016 \\
\hline
\end{tabular}

ridges in the Baltic. Due to limited flight capacity of the helicopter used, flights were restricted to regions close to the coast. The 2004 measurements were conducted from Hailuoto island (Haas, 2004b). The aim of the measurements was to collect data on sea ice ridges for developing satellite retrieval methods and numerical models.

HEM measurements in the winter of 2005 were part of the prelaunch campaign of the CryoSat satellite mission (Haas and Hendricks, 2005). Based on the satellite images, the flight tracks were designed to capture regions of the most deformed and thickest ice in the Bay of Bothnia in that year. Due to this arrangement, it is expected that the measurements are biased towards thick ice, and basin-wide mean ice thickness is probably less than the mean ice thickness of HEM measurements.

The POL-ICE project in 2005-2007 aimed to determine how operational sea ice monitoring in Finland can best benefit from forthcoming dual-polarized RADARSAT-2 SAR images. The goal of the POL-ICE field campaign in 2007 was to collect sea ice data for development and validation of sea ice products, e.g., ice types and ice thickness, based on dualpolarized ENVISAT and RADARSAT-2. EM surveys were carried out between 11 and 14 March and were co-incident as much as possible with the ENVISAT ASAR acquisitions (Hendricks et al., 2007).

The aim of the 2011 campaign was to examine the compression of pack ice and to obtain a synoptic view of the basin-wide ice thickness distribution in the Bay of Bothnia as a part of the SafeWin project (Kujala and Montewka, 2018). The winter of 2011 was severe and before the campaign, the Bay of Bothnia was covered by thick deformed ice. During the campaign, ice motion was very small, and hence the pack ice remained rather unchanged between the daily measurements. Additionally, weather conditions favored the campaign, and as an outcome, winter 2011 measurements are the most extensive HEM measurements in the Baltic. The 2011 campaign was used by Gegiuc et al. (2018) as validation data for the ice chart deformation numeral (degree of ice ridging). The agreement between the two data sets was generally good.

\subsubsection{Ship EM data}

Ship-based EM ice thickness measurements were performed on research cruises in 2012 and 2016 (Table 1). In these, the EM-31 instrument is placed in an enclosure and hung from a boom or a crane outside the ship hull (Haas, 1998). The ship measurements are often biased towards thin ice, as ship crews tend to avoid the thickest ice and turn back from impenetrable areas. These effects were minimized by deliberately searching for challenges (2012) or instructing the ship crew to make transects in straight lines whenever possible (2016).

The EM-31 instrument was generally $1-2 \mathrm{~m}$ above the water surface to avoid impacts from sea ice. The distance to the snow surface was measured with a laser rangefinder with a $10 \mathrm{~Hz}$ measuring frequency and a negligible footprint. Sea ice thickness is calculated separately for each rangefinder reading, and these thicknesses are averaged once per meter.

In 2012, ship EM measurements were conducted onboard the S.A. Agulhas II polar supply and research vessel during maneuver tests in an ice field. The objective of these tests was to test the ship performance in level ice, in ship channels with broken ice, and through pressure ridges in an ice field. Throughout these tests, vibration and forces on the ship hull were measured. The EM ice thickness data was collected both during the maneuver tests and the transit periods between them. During the test cruise the ice cover was small, and thick ridged ice was only found near the Hailuoto area.

Ship EM measurements from 2016 were part of the Aranda sea ice cruise. The objective of the mission was to carry out a cross-scientific study of the sea ice in the Bay of Bothnia. This included several experiments both during the transit and at the ice stations. Experiments ranged from remote sensing studies to ship transit in ice, basic measurements of sea ice physics, and biology in both sea ice and water. The EM data in this study was collected during the transit periods. The cruise track was not set before the mission, but approximate location of an ice station was always decided the night before based on the changing ice conditions. However, as much of the work as possible was planned to take place within the coverage of Hailuoto coastal radar. 

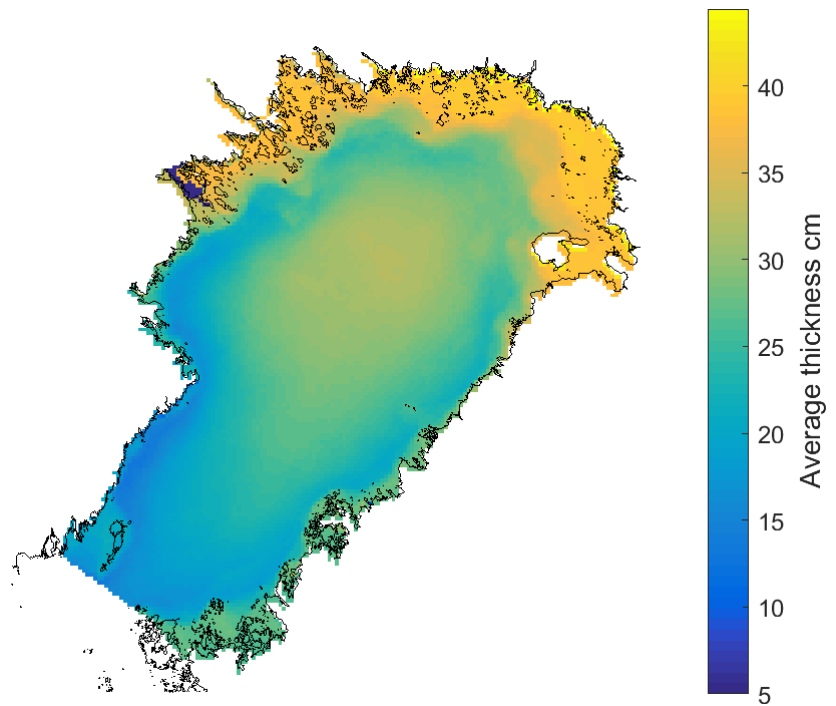

Figure 2. The average seasonal, level ice thickness from ice chart data. Values are averages of nonzero thickness values over 14 seasons.

\subsection{Drilling observations}

The in situ ice thickness measurements were made by drilling at the regular monitoring stations in the coastal fast ice zone. The original observations were made weekly throughout the winter. The lengths of the time series vary a lot; the longest time series is from Kemi station, where observations were made since 1912. There is no detailed documentation of the measurement sites available, so the sites might have moved, or the environment changed during the longer observation periods. For the period of 2003-2016, which is used in our analysis, the Hailuoto station was located on the southwest coast of the island $\left(64^{\circ} 56^{\prime} \mathrm{N}, 24^{\circ} 40^{\prime} \mathrm{E}\right.$, see Fig. 1).

\subsection{Atmospheric variables}

To investigate possible reasons behind the observed ice thickness variability, we calculated freezing degree days from air temperature observations in Hailuoto Keskikylä station $\left(65^{\circ} 1^{\prime} \mathrm{N}, 24^{\circ} 43^{\prime} \mathrm{E}\right)$ (FMI, 2018). Daily mean air temperatures are available since 1959. Freezing degree days are the annual cumulative sum of daily mean air temperatures below $0{ }^{\circ} \mathrm{C}$.

Another factor affecting ice thickness variability is wind. We analyzed days with wind speeds over $14 \mathrm{~m} \mathrm{~s}^{-1}$ during the winter months January, February, and March (JFM) in Hailuoto Marjaniemi station $\left(65^{\circ} 2^{\prime} \mathrm{N}, 24^{\circ} 33^{\prime} \mathrm{E}\right)$. This was based on $10 \mathrm{~min}$ average wind speeds, and observations were normally made 8 times per day since 1984. In some days in the 1980s and in the beginning of the 1990s less observations were made.
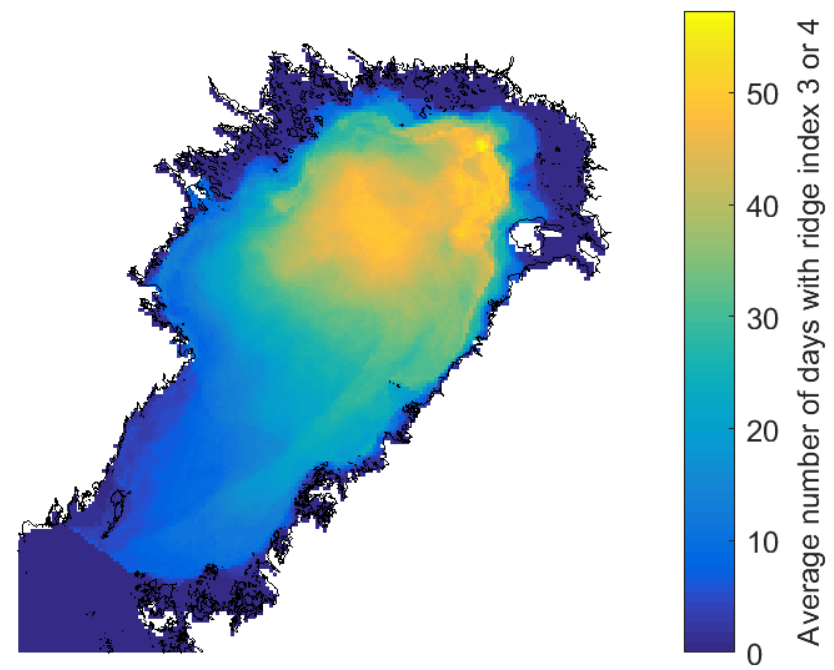

Figure 3. Average number of days with ice chart ridging index 3 (ridged ice) or 4 (heavily ridged ice).

Table 2. Maximum annual Baltic Sea ice extent (MIB) in the years of EM ice thickness surveys. MIB anomalies are based on years 1961-2010. Also listed are ice severity according to Finnish Ice Service, North Atlantic Oscillation (NAO) index, and the amount of freezing degree days in Hailuoto.

\begin{tabular}{rrclrr}
\hline Year & $\begin{array}{r}\text { MIB } \\
\left(\mathrm{km}^{2}\right)\end{array}$ & $\begin{array}{c}\text { MIB } \\
\text { anomaly }\end{array}$ & $\begin{array}{l}\text { MIB } \\
\text { severity }\end{array}$ & $\begin{array}{r}\text { NAO } \\
\text { index }\end{array}$ & $\begin{array}{r}\text { FDD } \\
\text { (degrees) }\end{array}$ \\
\hline 2003 & 233000 & + & Severe & -0.05 & 1345 \\
2004 & 153000 & - & Average & 0.07 & 879 \\
2005 & 178000 & - & Average & 0.89 & 773 \\
2007 & 140000 & - & Average & 0.36 & 822 \\
2011 & 309000 & + & Severe & -0.67 & 1430 \\
2012 & 179000 & - & Average & 1.37 & 779 \\
2016 & 110000 & - & Mild & 1.31 & 670 \\
\hline
\end{tabular}

In addition, to find out the influence of large-scale atmospheric forcing we used NAO index values from the NOAA Climate Prediction Center (NOAA Climate Prediction Center, 2018). The monthly values were averaged over December, January, and February (DJF).

\subsection{Severity of the EM data winters}

The severity of the winters from which we have EM data is presented in Table 2. This does not fully represent the severity of the winters in the time period of 2003-2016 due to a lack of measurements in the two really mild ice winters 2008 and 2015. The years that are presented here include only one winter which is classified as mild. However, five of the seven winters are milder than average between 1961 and 2010. The sum of freezing degree days is remarkably higher in the two severe winters 2003 and 2011. 


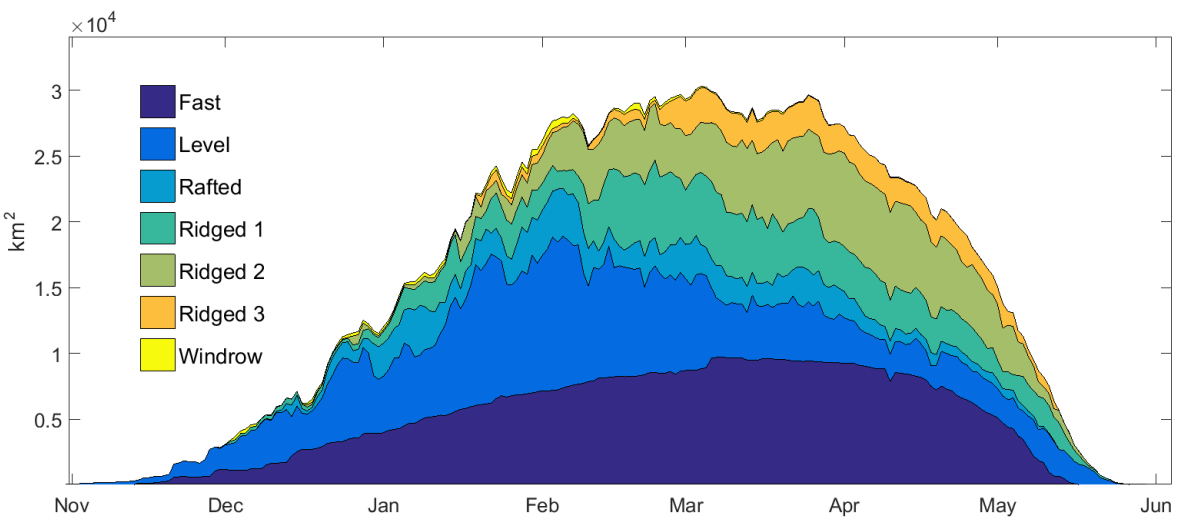

Figure 4. The seasonal development of charted ice area as divided into ice types. Season day averages over 14 seasons, including open water.

\section{Results}

\subsection{Ice charts}

We calculated the results from ice charts over 14 seasons in 2003-2016. The length of ice season (Fig. 1) varies from 69 days in the Quark to 157 days in the northern inlets. The basin mean value is 106 days. Self-evidently, the ice season is longer in the north than in the south, but the ice season is also longer in shallow coastal areas than in the middle of the basin.

The average ice thickness (Fig. 2) does not include days of open water. The values range from $0.11 \mathrm{~m}$ near the southwest coast to $0.44 \mathrm{~m}$ off the northeast land fast ice, the basin average being $0.28 \mathrm{~m}$. The effect of recurring coastal leads can be seen more prominently along the Swedish coast due to prevailing northwesterly winds. Also the extent of fast ice becomes delineated by the coastal leads. The impact of the prevailing wind pattern is also manifested as enhanced ridging in the northeast sector of the Bay of Bothnia (Fig. 3). Based on ice charts, ridges are common in that region every year, and on average, the duration of ridged or heavily ridged ice conditions is up to 57 days.

In Fig. 4 the seasonal development of the Bay of Bothnia ice area, which has been divided into different ice types, is shown. The ice types are fast ice and the six classes of ice deformation. The values for a given day are averages over the 14 seasons. The area of fast ice expands on average until the middle of March, begins to decline rapidly in the middle of April, and disappears in the middle of May. Drift ice disappears after fast ice has melted, and that is a feature typical for the basin. In the drift ice the level ice area increases to the beginning of February, at which stage, about half of the pack ice is also rafted or ridged. The level and rafted ice areas then decrease gradually while the ridged ice types increase so that in March $75 \%$ of pack ice area is rafted or ridged. The total ice area remains quasi-constant during February and March, before the beginning of the melting season in April. The ap- parent faster decline of ridged ice in comparison with level ice in late May is probably in part due to the disappearance of surface ridge signatures in radar images of the melting pack used for compiling the charts.

The thickness time series in Fig. 5 is derived for the daily basin averages for fast ice and drift ice thicknesses. Both the scattered values for individual seasons and the average over all 14 seasons are shown. The fast ice growth rate slows down until the thickness reaches $0.52 \mathrm{~m}$ before the last third of March. After this the thickness remains constant for a month and declines then rapidly. The average of ice chart ice thickness in the drift ice zone, which refers to regionally representative level or slightly rafted types, reaches $0.43 \mathrm{~m}$ before the melting period. The pack ice remains about 10 days after the fast ice has disappeared, probably due to its larger mean thickness.

\subsection{Helicopter EM data}

Grid-averaged HEM data from all years are compared with ice chart data in Fig. 6. The EM data were gathered during several days before and after the dates of the ice charts. The thicknesses in the ice charts are up to $0.5 \mathrm{~m}$. However, in many areas the EM thicknesses are up to and larger than $1 \mathrm{~m}$, the scale of the color bar of Fig. 6. This is due to the fact that the ice chart values are for ice with a flat surface, which is level or rafted ice. The helicopter EM measurements show the real situation with ridged ice in the drift ice zone.

Although the maps are not from exactly the same day from year to year, a large interannual variability can be seen in these 5 years. The mildest ice winter based on both data sets is 2005. In the severest years 2003 and 2011 the entire Bay of Bothnia was ice covered and over $1 \mathrm{~m}$ thick ice was also measured in the south near the Quark.

In ice charts the most spatially severe ice conditions are in the north. In addition, especially in 2003 and 2011 there was more ice in the eastern side of the bay. The EM data from 2003 and 2005 show that the ice was thicker in the northeast- 


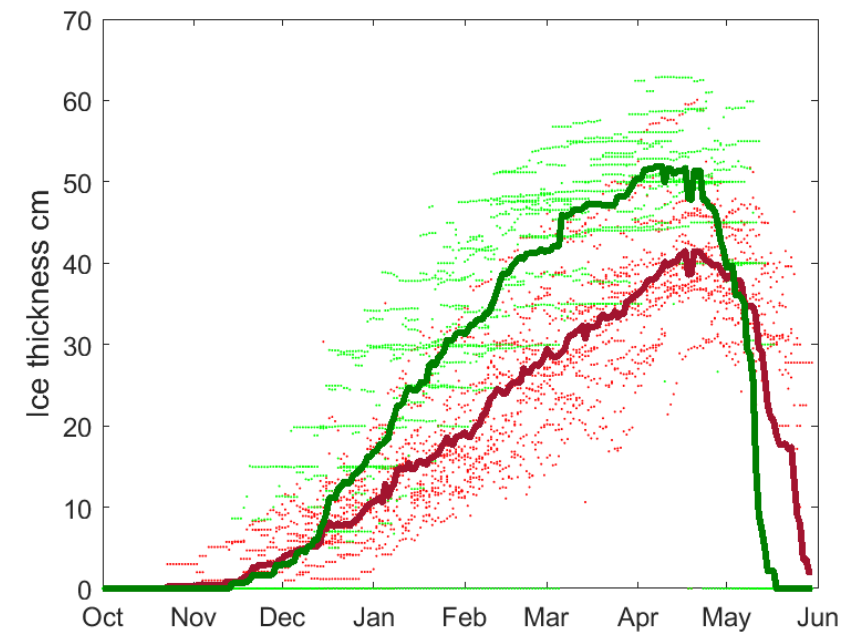

Figure 5. Seasonal development of level ice thickness. Data are based on ice chart information thickness for 14 seasons 2003-2016. The green and red dots are daily level ice thicknesses in the fast ice and pack ice zones for different seasons, the green line is fast ice thickness average over seasons, and the red line is pack ice thickness.

ern part. This is a result of dominant southwesterly winds in the area.

Histograms of grid-averaged HEM ice thicknesses are shown in Fig. 7. The mean ice thickness in 2003 was $0.98 \mathrm{~m}$ and the mode was $0.6-0.7 \mathrm{~m}$. The data from 2004 (Fig. 7b) are not as evenly distributed as in 2003 . There was a strong mode of $0.1-0.2 \mathrm{~m}$, representing thin new ice which has grown in coastal polynyas. However, the mean was $1.17 \mathrm{~m}$, and thicknesses over $1 \mathrm{~m}$ were more common than in other years. The thicker ice indicates that there was extensive ridged ice. The 2004 campaign was done in the northern Bay of Bothnia in a quite small area near Hailuoto.

The ice thickness from helicopter EM data from 2005 is presented in Fig. 7c. The mean was $0.78 \mathrm{~m}$ and the mode was $0.3-0.4 \mathrm{~m}$. In 2007 the mean was $0.76 \mathrm{~m}$, close to the mode of $0.5-0.6 \mathrm{~m}$, because the histogram was characterized by a high peak (Fig. 7d). Thick ice was rare in this campaign, which covered a wide region of the northern Bay of Bothnia. Thus, in 2007 ridged ice was rare. Instead, the observed distribution points to the fact that level and rafted ice might have been the dominating ice types. In 2011 the mean was $0.89 \mathrm{~m}$ and the mode was $0.3-0.4 \mathrm{~m}$ (Fig. 7e). The average from all 5 years is presented in Fig. 7f. The mean is $0.92 \mathrm{~m}$ and the mode is $0.4-0.5 \mathrm{~m}$.

\subsection{Coastal boundary zone}

EM-measured ice thicknesses, ice chart minimum and maximum thicknesses, and thickness measurements of fast ice for the years 2007 and 2011 are combined in Fig. 8. The thicknesses are presented as a function of distance from the fast
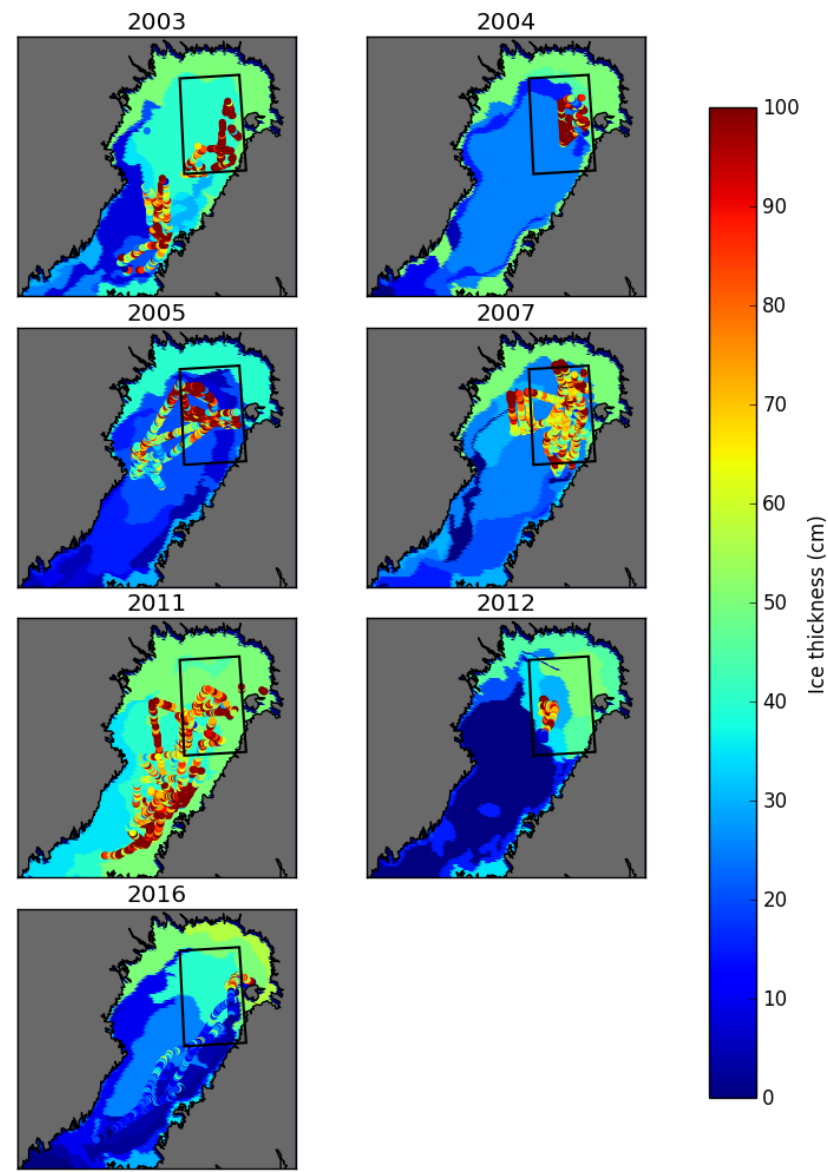

Figure 6. Ice chart (on the background) and 1 nautical mile averaged EM data (with dots). Ice charts are from 23 February 2003, 14 March 2004, 13 March 2005, 14 March 2007, 4 March 2011, 21 March 2012, and 5 March 2016. The dates of EM data are in Table 1. As we can see, the ice charts report uniform, thin ice, while in reality thick deformed ice types are typical. The black box is the area west of Hailuoto used in analysis. The limits of the area are in latitude $64.5-65.5^{\circ} \mathrm{N}$ and in longitude $23-24.5^{\circ} \mathrm{E}$.

ice edge. The years were chosen to be the two with the most representative spatial coverage of the coastal boundary zone.

Figure 8 shows that the EM-observed thickness in the drift ice zone is much thicker than the in situ observed fast ice thickness. The fast ice thickness was $0.51 \mathrm{~m}$ (2007) and $0.65 \mathrm{~m}$ (2011), whereas the mean ice thickness in the drift ice zone closest to the fast ice $(<5 \mathrm{~km})$ was $0.96 \mathrm{~m}$ (2007) and $1.21 \mathrm{~m}$ (2011).

The effect of the coast on drift ice thicknesses can be seen up to $20 \mathrm{~km}$ from the fast ice edge. EM-measured thicknesses are consistently larger close to the fast ice edge than farther away from it.

The variation in EM-observed thickness (vertical red bars in Fig. 8) is larger close to the coast than farther away from it. In other words, both the thickest and thinnest ice are found in the zone closer than $20 \mathrm{~km}$ from the fast ice edge. The large 

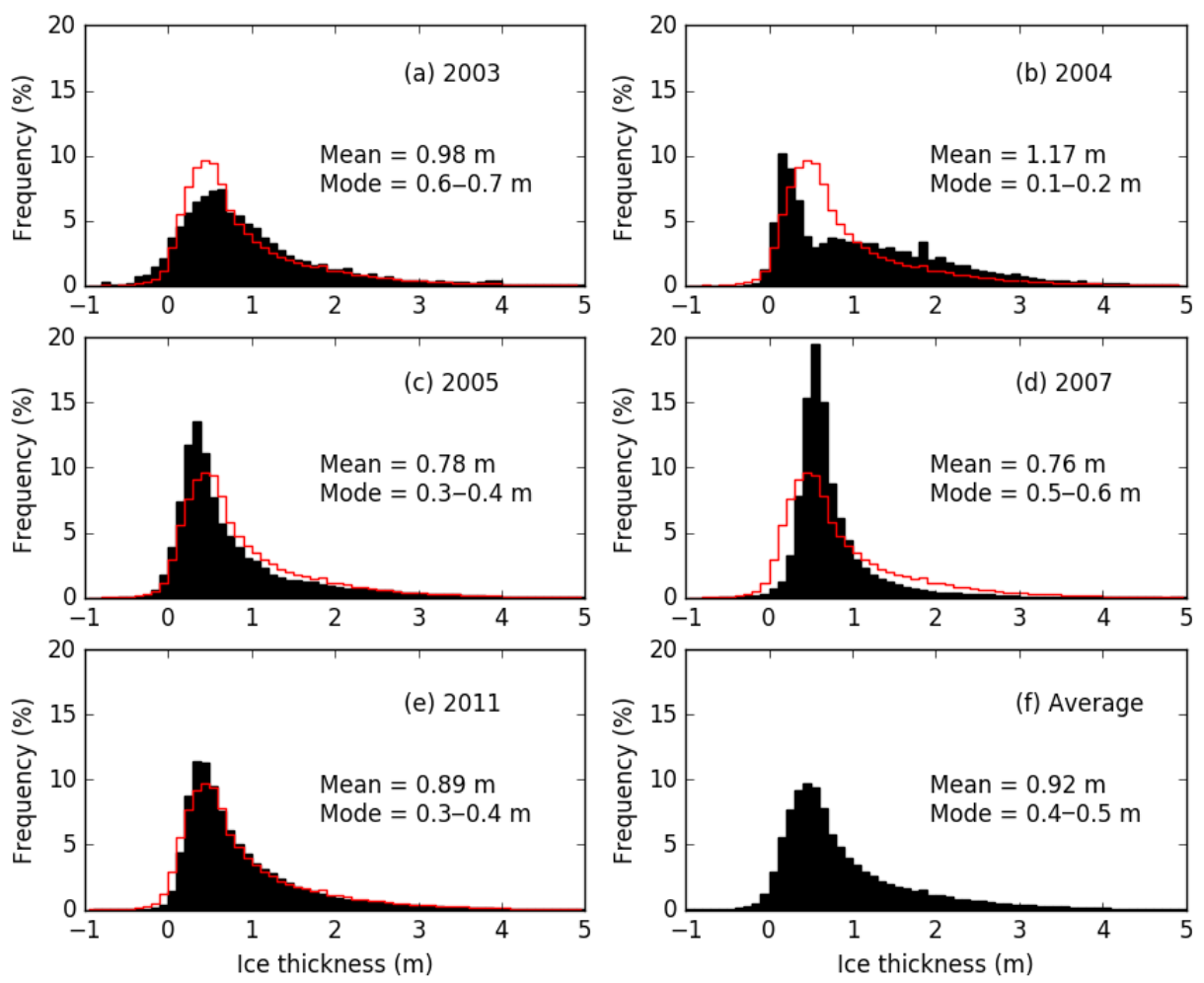

Figure 7. Frequency histograms of all helicopter EM ice thickness measurements in (a) 2003, (b) 2004, (c) 2005, (d) 2007, and (e) 2011 (in black). The average of all years is in panel (f) and in red in other panels. To avoid areal focus we have first calculated histograms in $1 \times 1$ $\mathrm{NM}^{2}$ grid for each grid point and then averaged all histograms from the grid points.

variability close to the fast ice edge can be explained by the repeated opening, refreezing, and closing of coastal leads, which creates both thin ice and thick ice when ridging against the barrier of the fast ice edge occurs during divergence and convergence events.

Figure 8 shows a large discrepancy between EM-observed ice thickness and the ice chart thickness. Based on this, we emphasize that ice chart thicknesses represent the thickness of undeformed, thermodynamically grown level ice and should not be used as a proxy for overall ice thickness, or volume, of drift ice.

\subsection{Fractions of deformed and level ice}

We calculated the fractions of deformed and level ice from the HEM data. As a threshold between the deformed and level ice, we used the drilling measurement in Hailuoto station in each year approximately on the 1 March (measurements made weekly). Deformed ice forms later than the fast ice and therefore is younger, and level ice thickness in the drift ice zone is not able to grow thicker than fast ice. That is why we use the fast ice thickness measurement as a threshold. By deformed ice we mean here rafted and ridged ice as well as rubble fields.
Table 3 shows the fractions of deformed and level ice both in the entire measurement area and in the area west of Hailuoto for all of the HEM data available. The area west of Hailuoto has been chosen because there are measurements from all years in the area. The limits of the area are in latitude 64.5$65.5^{\circ} \mathrm{N}$ and in longitude $23-24.5^{\circ} \mathrm{E}$ (see Fig. 6).

For all of the campaigns, the areal fraction of deformed ice is considerable. The minimum fraction for deformed ice of $49.7 \%$ was found during 2011 and the maximum of $70.4 \%$ during 2007. Interestingly, during the two severe ice winters (2003 and 2011) in our data set, we found the smallest (2011) and third smallest (2003) areal fractions of deformed ice.

In the area west of Hailuoto, there is usually much deformation. The fraction of deformed ice in 2003-2007 was $60 \%-70 \%$. Interestingly, the fraction was only $43.3 \%$ in 2011. Recalling that the winter of 2011 was severe in the Baltic, we assume that the thermodynamically grown ice was thick enough to reduce ice motion. That might explain the smaller fractions of deformed ice in severe winters in the entire Bay of Bothnia too.

\subsection{Interannual variability}

In Fig. 9 we have compared the different ice thickness data sets from 2003 to 2016 to each other. Drilling observations 
Table 3. The fraction of undeformed and deformed ice in helicopter EM measurements in the entire Bay of Bothnia and in the area west of Hailuoto. The drilling measurement in Hailuoto station in each year approximately on the 1 March has been used as a threshold between undeformed and deformed ice.

\begin{tabular}{rrrrrr}
\hline & \multicolumn{2}{c}{ Entire Bay of Bothnia } & & \multicolumn{2}{c}{ Area west of Hailuoto } \\
\cline { 2 - 3 } \cline { 5 - 6 } Year & Undeformed ice & Deformed ice & & Undeformed ice & Deformed ice \\
\hline 2003 & $48.4 \%$ & $51.6 \%$ & & $36.9 \%$ & $63.1 \%$ \\
2004 & $36.1 \%$ & $63.9 \%$ & & $36.1 \%$ & $63.9 \%$ \\
2005 & $50.1 \%$ & $49.9 \%$ & & $38.8 \%$ & $61.2 \%$ \\
2007 & $29.6 \%$ & $70.4 \%$ & & $31.1 \%$ & $68.9 \%$ \\
2011 & $50.3 \%$ & $49.7 \%$ & & $56.7 \%$ & $43.3 \%$ \\
\hline
\end{tabular}
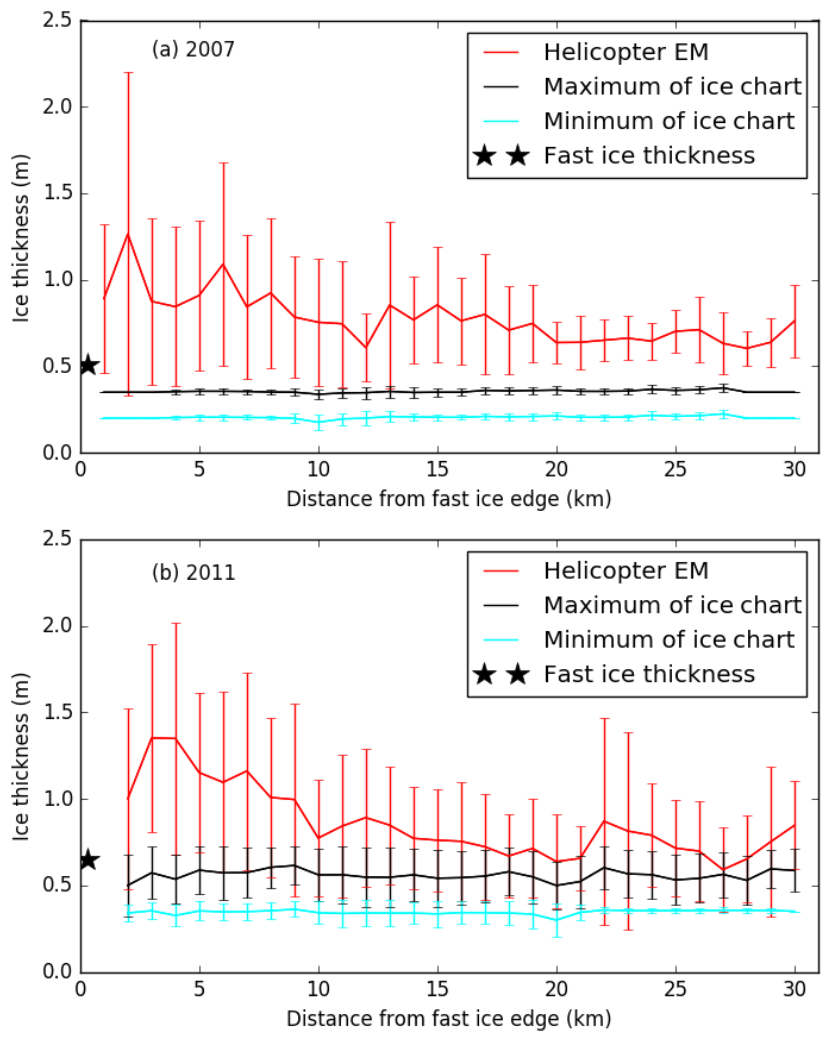

Figure 8. Ice thickness (a) 2007 and (b) 2011 from helicopter EM (red) and maximum (black) and minimum (cyan) of ice charts from the same points where helicopter EM was measured. Ice thickness is shown with the distance from the fast ice edge. The bars are \pm standard deviation and the stars indicate fast ice thickness on approximately 1 March in Hailuoto station.

from Hailuoto represent the fast ice zone. The ice chart data, HEM mean data, and ship EM mean data are averages over drift ice area west of Hailuoto (see Fig. 6). The HEM mode and ship EM mode are modes over the same drift ice area west of Hailuoto. In this figure the EM mean and mode values have been calculated from the entire data differently from the histograms. The ice charts are from 1 March and open water was not taken into account in mean values. The drilling
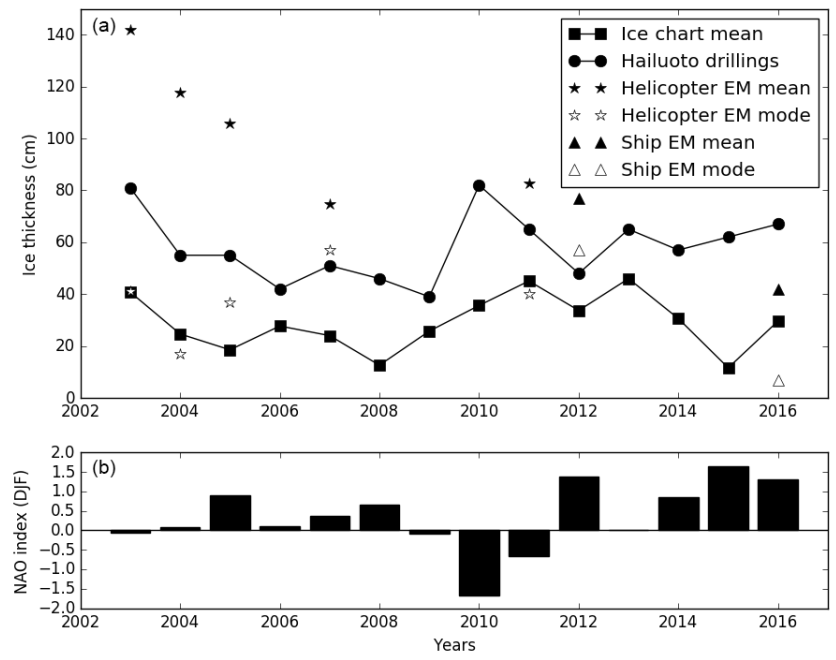

Figure 9. Time series of mean and modal ice thicknesses from Hailuoto drillings (circles) in the fast ice zone, ice charts (squares), helicopter EM surveys (black stars), and ship EM surveys (black triangles) in the drift ice area west of Hailuoto (a). Helicopter EM modes (white stars) and ship EM modes (white triangles) were also observed over drift ice area west of Hailuoto. Panel (b) shows time series of mean NAO index of winter months DJF. Data from years 2003 to 2016.

measurements are made weekly, so the day of the measurements varies between 26 February and 4 March. Figure 9 also shows the NAO index values for each winter. In addition, we have listed the amount of freezing degree days, wind days, and the value of NAO index in Table 4 together with the ice thickness values.

The largest ice thicknesses were observed by the HEM measurements, which indicate the drift ice thickness. HEM thickness histograms from this area are shown in Fig. 10. These were also averaged over $1 \times 1 \mathrm{NM}^{2}$ grid areas to avoid areal focus. The mean and mode marked in the histograms are calculated from the histograms unlike the values in Fig. 9 and Table 4.

In 2004, when all the measurements were made in this area, there was a lot of thin ice. Thick, ridged ice also existed 

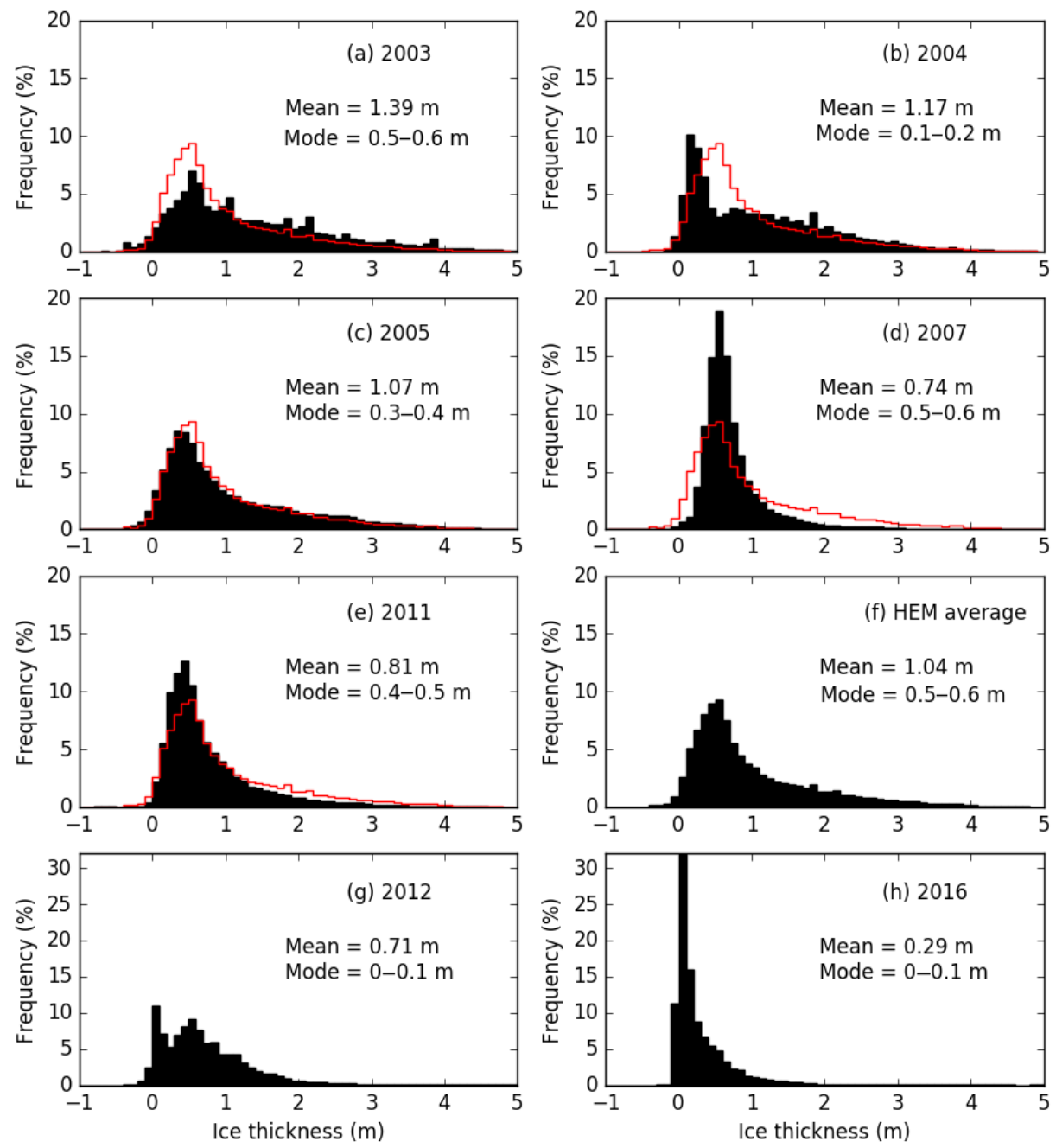

Figure 10. Frequency histograms of helicopter EM ice thickness in the drift ice area west of Hailuoto for (a) 2003, (b) 2004, (c) 2005, (d) 2007, and (e) 2011 (in black). The average of all years of HEM is in panel (f) and in red in other panels. Frequency histograms of ship EM ice thickness in the drift ice area west of Hailuoto (g) 2012 and (h) 2016. To avoid areal focus we have first calculated histograms in a $1 \times 1 \mathrm{NM}^{2}$ grid for each grid point and then averaged all histograms from the grid points.

during this average winter in terms of freezing degree days. These kind of ice conditions would be expected when there is a lot of wind. However, in 2004 there were only 10 days of wind over $14 \mathrm{~m} \mathrm{~s}^{-1}$, which is less than average of 20032016.

Compared to the results of the entire campaign in 2005, there is more thick ice in the selected area. This is clearly seen also in Fig. 6, where the thickest ice was found in northern parts of the campaign in 2005. Year 2007 was mild, and there were 9 wind days. Thus, the thick ice was almost completely missing. In 2011 there was a higher peak in the histogram of the selected area compared to the histogram of the entire campaign. The 2011 campaign was the broadest of all campaigns. It was the most severe winter in terms of freezing degree days, but in spite of the 15 winds days, there was not much thick, ridged ice.
The histograms of ship EM from the selected area are also included in Fig. 10. In both winters 2012 and 2016 the modal thickness was $0-0.1 \mathrm{~m}$. Particularly in 2016 there was a lot of thin ice, and the mean was only $0.29 \mathrm{~m}$. This winter was the mildest from the EM data years in terms of freezing degree days and maximum annual ice extent in the Baltic Sea.

The ice chart mean values show that there is much variability between years in the drift ice zone's level ice thickness. Based on ice charts the mildest ice winters were 2015 and 2008. However, in the drilling observations the year 2009 was milder. In the freezing degree days the mildest winter was 2014 and the severest 2011. The most wind days occurred in the mild winter of 2015. Nevertheless, the second windiest winter was the severe winter of 2003, where the EM data found the thickest ice and large amount of ridged ice. 
Table 4. Ice thickness observations, atmospheric variables, and their statistics from winters 2003 to 2016. Drillings are ice thickness drillings from Hailuoto approximately on 1 March, ice charts data is the mean from the area west of Hailuoto on 1 March (open water not taken into account), EM mean is the EM mean ice thickness in the same area, and EM mode is the mode thickness in the area. In EM data, HEM means helicopter-borne EM, and SEM means shipborne. FDD is the amount of freezing degree days during the winter in Hailuoto, wind days are days with wind over $14 \mathrm{~m} \mathrm{~s}^{-1}$ in JFM in Hailuoto, and NAO index is average value for winter months DJF.

\begin{tabular}{|c|c|c|c|c|c|c|c|}
\hline Year & $\begin{array}{r}\text { Drillings } \\
(\mathrm{m})\end{array}$ & $\begin{array}{r}\text { Ice charts } \\
(\mathrm{m})\end{array}$ & $\begin{array}{l}\text { EM mean } \\
(\mathrm{m})\end{array}$ & $\begin{array}{l}\text { EM mode } \\
(\mathrm{m})\end{array}$ & $\begin{array}{r}\text { FDD } \\
\text { (degrees) }\end{array}$ & $\begin{array}{r}\text { Wind days } \\
\text { (d) }\end{array}$ & $\begin{array}{l}\text { NAO } \\
\text { index }\end{array}$ \\
\hline 2003 & 0.81 & 0.41 & 1.42 (HEM) & 0.41 (HEM) & 1345 & 18 & -0.05 \\
\hline 2004 & 0.55 & 0.25 & 1.18 (HEM) & 0.17 (HEM) & 879 & 10 & 0.07 \\
\hline 2005 & 0.55 & 0.19 & 1.06 (HEM) & 0.37 (HEM) & 773 & 15 & 0.89 \\
\hline 2006 & 0.42 & 0.28 & & & 1090 & 8 & 0.10 \\
\hline 2007 & 0.51 & 0.24 & 0.75 (HEM) & 0.57 (HEM) & 822 & 9 & 0.36 \\
\hline 2008 & 0.46 & 0.13 & & & 521 & 7 & 0.66 \\
\hline 2009 & 0.39 & 0.26 & & & 728 & 13 & -0.08 \\
\hline 2010 & 0.82 & 0.36 & & & 1293 & 6 & -1.67 \\
\hline 2011 & 0.65 & 0.45 & 0.84 (HEM) & 0.40 (HEM) & 1430 & 15 & -0.67 \\
\hline 2012 & 0.48 & 0.34 & 0.77 (SEM) & 0.57 (SEM) & 779 & 11 & 1.37 \\
\hline 2013 & 0.65 & 0.46 & & & 1183 & 8 & 0.02 \\
\hline 2014 & 0.57 & 0.31 & & & 509 & 15 & 0.86 \\
\hline 2015 & 0.62 & 0.12 & & & 512 & 24 & 1.66 \\
\hline 2016 & 0.67 & 0.30 & 0.42 (SEM) & 0.07 (SEM) & 670 & 5 & 1.31 \\
\hline Mean & 0.58 & 0.29 & 0.92 & 0.37 & 895 & 12 & 0.34 \\
\hline $\mathrm{SD}$ & 0.13 & 0.11 & 0.33 & 0.19 & 318 & 5 & 0.88 \\
\hline Median & 0.56 & 0.29 & 0.84 & 0.40 & 801 & 11 & 0.23 \\
\hline Min & 0.39 & 0.12 & 0.42 & 0.07 & 509 & 5 & -1.67 \\
\hline Max & 0.82 & 0.46 & 1.42 & 0.57 & 1430 & 24 & 1.66 \\
\hline
\end{tabular}

\section{Discussion}

Our data show that there is large interannual ice thickness variability, although it is difficult to directly compare the EM data from different years. In some years areas with heavily ridged ice form, and there is much deformed ice in the Bay of Bothnia. However, in other years, for example in 2007, thinner ice dominates, and there is no thick ice. The winter of 2004 was milder and less windy than average, yet we found that both thick, ridged ice and thin, new ice formed during that year. In 2015 the Bay of Bothnia remained partly ice-free for the first time so that it was reliably recorded by satellites (Uotila et al., 2015). In our atmospheric data the winter of 2015 was the windiest and one of the mildest. The ice chart mean ice thickness in the area west of Hailuoto indicates level ice thickness of only $0.12 \mathrm{~m}$. The winter air temperature was still so low that in Hailuoto there was $0.62 \mathrm{~m}$ fast ice on 2 March 2015. Generally, fast ice thickness varies much less than the thickness of drift ice.

The average extent of the fast ice zone can be seen in Fig. 2. In Hailuoto the long-term maximum ice thickness in the fast ice zone for years 2003-2016 was $0.86 \mathrm{~m}$ in 2010 . The maximum thickness is usually reached in mid-March. The record value is $1.22 \mathrm{~m}$ from 1985 in Tornio (Leppäranta and Myrberg, 2009). The most ridged areas are in the northeastern Bay of Bothnia near the line of the fast ice zone. This is because of dominating winds from southwest. Even in mild winters high ridges form in the Bay of Bothnia. However, they cover a smaller area than in more severe winters.

Heavily ridged areas are found near the fast ice boundary. In the Bay of Bothnia they lie mostly in the northeastern corner as can be seen from Fig. 3. Oikkonen et al. (2016) found out that the drift of ice was anisotropic on coastal boundary zone, and that was due to effect of the coast. The alongshore component of the drift was larger than the cross-shore component. The drift speed was smaller near the fast ice (Oikkonen et al., 2016), which is consistent with our result that ice is thicker near the fast ice edge. The thicker the ice is, the less it moves. Our EM data shows that the ice thickness in the heavily ridged areas in scales of tens of square kilometers can be much thicker than the fast ice. These areas are challenging for winter navigation and are biological hot spots in spring as the ice melts last. Our results in Sect. 3.3 highlight the importance of coastal boundary zone for ice production. In these areas ridging or opening of leads are constantly occurring.

The effect of large-scale atmospheric circulation on ice extent and ice concentration in the Baltic Sea was studied by Vihma and Haapala (2009) and Vihma et al. (2014). Positive NAO index values indicate milder ice conditions, and negative NAO index values more severe conditions. In addition, Koslowski and Loewe (1994) showed that accumulated areal 


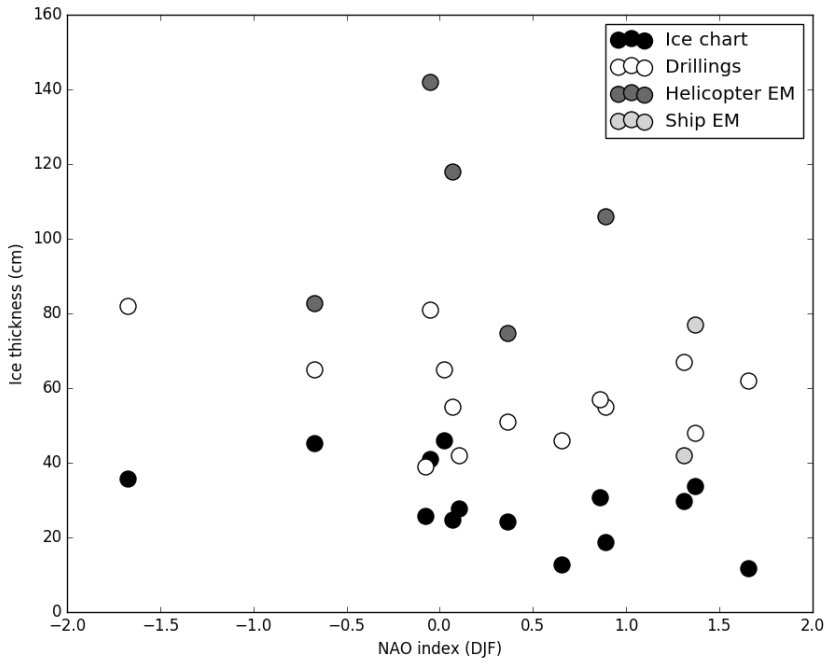

Figure 11. NAO index (DJF) and ice thickness from ice charts (black), drillings (white), helicopter EM surveys (dark grey), and ship EM surveys (light grey) for 2003-2016.

ice volume was negatively correlated with NAO index in a small area in the southwestern Baltic Sea. Research on the correlation of the NAO index purely with ice thickness is still lacking. However, ice thickness is a more complex variable than, for example, ice extent. Winters with a strongly positive NAO index, such as 2015 , are generally mild and windy. Wind piles up the ice, and conditions can be like in 2004, when in our study both thick, ridged ice and thin, new ice existed.

The correlation coefficient of the NAO index and the ice chart level ice thickness is -0.53 in our study period of 2003-2016 (Fig. 11). The correlation of the NAO index and drilling data is -0.38 . Neither of the correlations is statistically significant. Thus, our study does not show any significant correlation between NAO and level ice thickness. However, our time period is too short to capture the long-term behavior of the variables. The shortness of our data set limits our ability to determine the effect of the NAO index on ice thickness. However, our hypothesis is that in winters with a negative NAO index, more ice is produced. Our study period is too short for defining climate variations too, especially because the interannual variability in the area is so large.

We found no notable correlation between the amount of days of wind over $14 \mathrm{~m} \mathrm{~s}^{-1}$ and the amount of freezing degree days. This can be due to changing circumstances during each winter, like in 1986 when the NAO index was strongly negative in February and positive in other winter months (Vihma and Haapala, 2009).

Although studies concerning variability of deformed ice have not been carried out in the Baltic Sea, our results can be compared to studies from Arctic and Antarctic. King et al. (2017) used helicopter EM data from years 2003 and 2014 from the Barents Sea to determine the sea ice thickness. As in our study, large interannual and spatial variability was found. In 2003 regional modal ice thicknesses were $0.6-1.4 \mathrm{~m}$ and in 2014 they were $0.5-0.8 \mathrm{~m}$ (King et al., 2017). When comparing to Arctic and Antarctic surveys, it has to be remembered that there is no multiyear ice in the Baltic Sea. For example, EM measurements in Fram Strait between 2001 and 2012 show a decrease in both modal and mean ice thicknesses (Krumpen et al., 2016). However, the age of the ice has decreased from 3 to 2 years in 1990-2012. As also in our study, because of the short time series, definite conclusions of the thinning trend in ice thickness cannot be done from the study by Krumpen et al. (2016).

In the Antarctic, Sugimoto et al. (2016) also found large interannual variability in sea ice thickness by using shipborne EM data and visual observations in 2001-2012. From their analysis, the same tendency as seen in our results that the ice thickness is larger near the fast ice edge can be seen as well. Worby et al. (2008) defined the total Antarctic sea ice thickness from ship-based observations as $0.87 \pm 0.91 \mathrm{~m}$. In our study, the mean of the drift ice thickness is $0.92 \mathrm{~m}$, whereas the standard deviation is remarkably smaller $(0.33 \mathrm{~m})$, although our study area is smaller. Worby et al. (2008) also concluded that the mean ice thickness, including ridges, was $40 \%$ greater than the mean level ice thickness. Our results show that the in the Bay of Bothnia, the mean ice thickness from helicopter EM measurements is $217 \%$ greater than the mean level ice thickness from ice charts.

\section{Conclusions}

We have examined different data sets of ice thickness from the Bay of Bothnia in order to define the interannual variability of sea ice thickness. Different data sets describe different parts or different ice types in the Bay of Bothnia. Nevertheless, we found large variability both in time and space.

The interannual variability in the fast ice zone is much smaller than in the drift ice zone. Deformed ice has a major role in the drift ice zone. In some years there is mainly thin, thermodynamically grown ice even in the drift ice zone, and in some years large areas with thick ridges exist. Most of the years are a mixture of these two. Ice thickness varies even in a few days time due to advection or ridging, especially in the drift ice zone. Thus, our observations do not describe the absolute interannual variability.

Also large regional differences can be detected. The driving forces are wind and air temperature. Ice conditions are more severe in the north because of the colder air temperatures. Therefore the ice in this region is older and experiences more deformation to accumulate more ridges. The typical wind direction in the area is southwest. Southwest winds gather ice towards the northeastern area of the Bay of Bothnia, where ice conditions are more severe. The southwest corner is the mildest. 
In the drift ice zone the fraction of deformed ice is more than half of the total volume. In heavily ridged ice regions near the fast ice edge, mean ice thicknesses were $0.45-0.56 \mathrm{~m}$ thicker than the purely thermodynamically grown fast ice.

We emphasize that the ice thickness indicated in the ice charts underestimates real ice thickness of drift ice. Ice charts are based on a limited number of undeformed ice observations, but in particular, mean ice thickness in the coastal boundary zone can be 2-3 times larger than the thickness of purely thermodynamically grown undeformed ice.

Our attempt to solve the interannual variability showed that the winters are really different from each other. However, there is so much variability between years and between measurement methods that our results cannot be seen as absolute differences from year to year, only as rough indications of the ice thickness variability and change in the seasonal sea ice zone.

Data availability. The helicopter EM data from years 2003, 2004, 2005, and 2007 are available at PANGAEA. The Haas, Haas and Hendricks, and Pfaffling et al. data sets from PANGAEA are listed in the references. The monthly NAO index values are available at http://www.cpc.ncep.noaa.gov/products/precip/CWlink/pna/ norm.nao.monthly.b5001.current.ascii (NOAA Climate Prediction Center, 2018). The daily air temperature data are available at the Finnish Meteorological Institute's observation download service: https://en.ilmatieteenlaitos.fi/download-observations\#!/ (FMI, 2018). The other data sets are available from Finnish Meteorological Institute upon request.

Author contributions. IR carried out the drilling data and NAO index analysis. JL performed the shipborne EM analysis. Helicopter EM analysis was done by IR and JL. ML analyzed the ice chart data. The data analysis was done under the supervision of $\mathrm{JH}$ and $\mathrm{CH}$. $\mathrm{ER}, \mathrm{JH}$, and $\mathrm{CH}$ contributed to the interpretation of the results. IR led the manuscript writing with contributions from all co-authors.

Competing interests. The authors declare that they have no conflict of interest.

Acknowledgements. This research has been supported by a grant from the Vilho, Yrjö and Kalle Väisälä Foundation. Airborne EM surveys were funded by the EU projects IRIS and SafeWin. Andi Pfaffling, Stefan Hendricks, and Alec Casey contributed to the HEM data collection.

Edited by: John Yackel

Reviewed by: two anonymous referees

\section{References}

Eicken, H., Gradinger, R., Salganek, M., Shirasawa, K., Perovich, D., and Leppäranta, M. (Eds.): Field techniques for Sea-ice Research, University of Alaska Press, Fairbanks, 2009.

FMI: Search for FMI's daily air temperature data, Finnish Meteorological Institute's Download observations, available at: https://en.ilmatieteenlaitos.fi/download-observations\#!/, last access: 26 October 2018.

Gegiuc, A., Similä, M., Karvonen, J., Lensu, M., Mäkynen, M., and Vainio, J.: Estimation of degree of sea ice ridging based on dual-polarized C-band SAR data, The Cryosphere, 12, 343-364, https://doi.org/10.5194/tc-12-343-2018, 2018.

Haapala, J., Ronkainen, I., Schmeltzer, N., and Sztobryn, M.: Recent Change - Sea Ice, in: Second Assessment of Climate Change for the Baltic Sea Basin, edited by: BACC II Author team, Springer, 145-153, 2015.

Haas, C.: Evaluation of ship-based electromagnetic-inductive thickness measurements of summer sea-ice in the Bellingshausen and Amundsen Seas, Antarctica, Cold Reg. Sci. Technol., 27, 1-16, 1998.

Haas, C.: Airborne EM measurements of Baltic ice thickness in February 2003: The campaign, IRIS field report, Alfred Wegener Institute for Polar and Marine Research (AWI), Bremerhaven, Germany, 2003.

Haas, C.: Airborne EM sea-ice thickness profiling over brackish Baltic Sea water, in: Proceedings of the 17th international IAHR symposium on ice, 21-25 June 2004, St. Petersburg, Russia, AllRussian Research Institute of Hydraulic Engineering (VNIIG), Saint Petersburg, Russia, 2004a.

Haas, C.: EM ice thickness measurements during 2004 IRIS field campaign: 8 February to 17 March 2004, Sea ice physics, Alfred Wegener Institute for Polar and Marine Research, Bremerhaven, 2004b.

Haas, C.: Helicopter-borne sea ice thickness measurements during campaign IRIS2004 from flight IRIS2004_01, PANGAEA, https://doi.org/10.1594/PANGAEA.326881, 2005.

Haas, C.: Helicopter-borne sea ice thickness measurements during campaign IRIS2004 from flight IRIS2004_02, PANGAEA, https://doi.org/10.1594/PANGAEA.326882, 2005.

Haas, C.: Helicopter-borne sea ice thickness measurements during campaign IRIS2004 from flight IRIS2004_03, PANGAEA, https://doi.org/10.1594/PANGAEA.326883, 2005.

Haas, C.: Helicopter-borne sea ice thickness measurements during campaign IRIS2004 from flight IRIS2004_04, PANGAEA, https://doi.org/10.1594/PANGAEA.326884, 2005.

Haas, C.: Helicopter-borne sea ice thickness measurements during campaign IRIS2004 from flight IRIS2004_05, PANGAEA, https://doi.org/10.1594/PANGAEA.326885, 2005.

Haas, C.: Helicopter-borne sea ice thickness measurements during campaign IRIS2004 from flight IRIS2004_06, PANGAEA, https://doi.org/10.1594/PANGAEA.326886, 2005.

Haas, C.: Helicopter-borne sea ice thickness measurements during campaign IRIS2004 from flight IRIS2004_07, PANGAEA, https://doi.org/10.1594/PANGAEA.326887, 2005.

Haas, C.: Helicopter-borne sea ice thickness measurements during campaign IRIS2004 from flight IRIS2004_08, PANGAEA, https://doi.org/10.1594/PANGAEA.319921, 2005. 
Haas, C.: Helicopter-borne sea ice thickness measurements during campaign IRIS2004 from flight IRIS2004_09, PANGAEA, https://doi.org/10.1594/PANGAEA.326888, 2005.

Haas, C.: Helicopter-borne sea ice thickness measurements during campaign IRIS2004 from flight IRIS2004_10, PANGAEA, https://doi.org/10.1594/PANGAEA.326889, 2005.

Haas, C.: Helicopter-borne sea ice thickness measurements during campaign IRIS2004 from flight IRIS2004_11, PANGAEA, https://doi.org/10.1594/PANGAEA.326890, 2005.

Haas, C.: Helicopter-borne sea ice thickness measurements during campaign IRIS2004 from flight IRIS2004_12, PANGAEA, https://doi.org/10.1594/PANGAEA.326891, 2005.

Haas, C.: Helicopter-borne sea ice thickness measurements during campaign IRIS2004 from flight IRIS2004_13, PANGAEA, https://doi.org/10.1594/PANGAEA.326892, 2005.

Haas, C.: Helicopter-borne sea ice thickness measurements during campaign IRIS2004 from flight IRIS2004_14, PANGAEA, https://doi.org/10.1594/PANGAEA.326893, 2005.

Haas, C.: Helicopter-borne sea ice thickness measurements during campaign IRIS2004 from flight IRIS2004_15, PANGAEA, https://doi.org/10.1594/PANGAEA.326894, 2005.

Haas, C.: Helicopter-borne sea ice thickness measurements during campaign IRIS2004 from flight IRIS2004_16, PANGAEA, https://doi.org/10.1594/PANGAEA.326895, 2005.

Haas, C.: Helicopter-borne sea ice thickness measurements during campaign IRIS2004 from flight IRIS2004_17, PANGAEA, https://doi.org/10.1594/PANGAEA.326896, 2005.

Haas, C.: Helicopter-borne sea ice thickness measurements during campaign IRIS2004 from flight IRIS2004_18, PANGAEA, https://doi.org/10.1594/PANGAEA.326897, 2005.

Haas, C.: Helicopter-borne sea ice thickness measurements during campaign IRIS2004 from flight IRIS2004_19, PANGAEA, https://doi.org/10.1594/PANGAEA.326898, 2005.

Haas, C.: Helicopter-borne sea ice thickness measurements during campaign IRIS2004 from flight IRIS2004_20, PANGAEA, https://doi.org/10.1594/PANGAEA.326899, 2005.

Haas, C.: Helicopter-borne sea ice thickness measurements during campaign IRIS2004 from flight IRIS2004_21, PANGAEA, https://doi.org/10.1594/PANGAEA.326900, 2005.

Haas, C.: Helicopter-borne sea ice thickness measurements during campaign IRIS2004 from flight IRIS2004_22, PANGAEA, https://doi.org/10.1594/PANGAEA.326901, 2005.

Haas, C.: Helicopter-borne sea ice thickness measurements during campaign IRIS2004 from flight IRIS2004_23, PANGAEA, https://doi.org/10.1594/PANGAEA.326902, 2005.

Haas, C.: Helicopter-borne sea ice thickness measurements during campaign IRIS2004 from flight IRIS2004_24, PANGAEA, https://doi.org/10.1594/PANGAEA.326903, 2005.

Haas, C.: Helicopter-borne sea ice thickness measurements during campaign IRIS2004 from flight IRIS2004_25, PANGAEA, https://doi.org/10.1594/PANGAEA.326904, 2005.

Haas, C.: Helicopter-borne sea ice thickness measurements during campaign IRIS2004 from flight IRIS2004_26, PANGAEA, https://doi.org/10.1594/PANGAEA.326905, 2005.

Haas, C.: Helicopter-borne sea ice thickness measurements during campaign IRIS2004 from flight IRIS2004_27, PANGAEA, https://doi.org/10.1594/PANGAEA.326906, 2005.
Haas, C.: Helicopter-borne sea ice thickness measurements during campaign IRIS2004 from flight IRIS2004_28, PANGAEA, https://doi.org/10.1594/PANGAEA.326907, 2005.

Haas, C.: Helicopter-borne sea ice thickness measurements during campaign IRIS2004 from flight IRIS2004_29, PANGAEA, https://doi.org/10.1594/PANGAEA.326908, 2005.

Haas, C.: Helicopter-borne sea ice thickness measurements during campaign IRIS2004 from flight IRIS2004_30, PANGAEA, https://doi.org/10.1594/PANGAEA.326909, 2005.

Haas, C.: Helicopter-borne sea ice thickness measurements during campaign IRIS2004 from flight IRIS2004_31, PANGAEA, https://doi.org/10.1594/PANGAEA.326910, 2005.

Haas, C.: Helicopter-borne sea ice thickness measurements during campaign IRIS2004 from flight IRIS2004_32, PANGAEA, https://doi.org/10.1594/PANGAEA.326911, 2005.

Haas, C.: Helicopter-borne sea ice thickness measurements during campaign IRIS2004 from flight IRIS2004_33, PANGAEA, https://doi.org/10.1594/PANGAEA.326912, 2005.

Haas, C.: Helicopter-borne sea ice thickness measurements during campaign IRIS2004 from flight IRIS2004_34, PANGAEA https://doi.org/10.1594/PANGAEA.326913, 2005.

Haas, C.: Helicopter-borne sea ice thickness measurements during campaign IRIS2004 from flight IRIS2004_35, PANGAEA, https://doi.org/10.1594/PANGAEA.326914, 2005.

Haas, C.: Helicopter-borne sea ice thickness measurements during campaign IRIS2004 from flight IRIS2004_36, PANGAEA, https://doi.org/10.1594/PANGAEA.326915, 2005.

Haas, C.: Helicopter-borne sea ice thickness measurements during campaign IRIS2004 from flight IRIS2004_37, PANGAEA, https://doi.org/10.1594/PANGAEA.326916, 2005.

Haas, C.: Helicopter-borne sea ice thickness measurements during campaign IRIS2004 from flight IRIS2004_38, PANGAEA, https://doi.org/10.1594/PANGAEA.326917, 2005.

Haas, C.: Helicopter-borne sea ice thickness measurements during campaign IRIS2004 from flight IRIS2004_39, PANGAEA, https://doi.org/10.1594/PANGAEA.326918, 2005.

Haas, C.: Helicopter-borne sea ice thickness measurements during campaign IRIS2004 from flight IRIS2004_40, PANGAEA, https://doi.org/10.1594/PANGAEA.326919, 2005.

Haas, C.: Helicopter-borne sea ice thickness measurements during campaign IRIS2004 from flight IRIS2004_41, PANGAEA, https://doi.org/10.1594/PANGAEA.326920, 2005.

Haas, C.: Helicopter-borne sea ice thickness measurements during campaign IRIS2004 from flight IRIS2004_42, PANGAEA, https://doi.org/10.1594/PANGAEA.326921, 2005.

Haas, C.: Helicopter-borne sea ice thickness measurements during campaign IRIS2004 from flight IRIS2004_43, PANGAEA, https://doi.org/10.1594/PANGAEA.326922, 2005.

Haas, C.: Helicopter-borne sea ice thickness measurements during campaign IRIS2004 from flight IRIS2004_44, PANGAEA, https://doi.org/10.1594/PANGAEA.326923, 2005.

Haas, C.: Helicopter-borne sea ice thickness measurements during campaign IRIS2004 from flight IRIS2004_45, PANGAEA, https://doi.org/10.1594/PANGAEA.326924, 2005.

Haas, C.: Helicopter-borne sea ice thickness measurements during campaign IRIS2004 from flight IRIS2004_46, PANGAEA, https://doi.org/10.1594/PANGAEA.326925, 2005. 
Haas, C.: Helicopter-borne sea ice thickness measurements during campaign IRIS2004 from flight IRIS2004_47, PANGAEA, https://doi.org/10.1594/PANGAEA.326926, 2005.

Haas, C.: Helicopter-borne sea ice thickness measurements during campaign IRIS2004 from flight IRIS2004_48, PANGAEA, https://doi.org/10.1594/PANGAEA.326927, 2005.

Haas, C.: Helicopter-borne sea ice thickness measurements during campaign IRIS2004 from flight IRIS2004_49, PANGAEA, https://doi.org/10.1594/PANGAEA.326928, 2005.

Haas, C.: Helicopter-borne sea ice thickness measurements during campaign IRIS2004 from flight IRIS2004_50, PANGAEA, https://doi.org/10.1594/PANGAEA.326929, 2005.

Haas, C.: Helicopter-borne sea ice thickness measurements during campaign IRIS2004 from flight IRIS2004_51, PANGAEA, https://doi.org/10.1594/PANGAEA.326930, 2005.

Haas, C.: Helicopter-borne sea ice thickness measurements during campaign IRIS2004 from flight IRIS2004_52, PANGAEA, https://doi.org/10.1594/PANGAEA.326931, 2005.

Haas, C.: Helicopter-borne sea ice thickness measurements during campaign IRIS2004 from flight IRIS2004_53, PANGAEA, https://doi.org/10.1594/PANGAEA.326932, 2005.

Haas, C.: Helicopter-borne sea ice thickness measurements during campaign IRIS2004 from flight IRIS2004_54, PANGAEA, https://doi.org/10.1594/PANGAEA.326933, 2005.

Haas, C.: Helicopter-borne sea ice thickness measurements during campaign IRIS2004 from flight IRIS2004_55, PANGAEA, https://doi.org/10.1594/PANGAEA.326934, 2005.

Haas, C.: Helicopter-borne sea ice thickness measurements during campaign IRIS2004 from flight IRIS2004_56, PANGAEA, https://doi.org/10.1594/PANGAEA.326935, 2005.

Haas, C.: Helicopter-borne sea ice thickness measurements during campaign IRIS2004 from flight IRIS2004_57, PANGAEA, https://doi.org/10.1594/PANGAEA.326936, 2005.

Haas, C.: Helicopter-borne sea ice thickness measurements during campaign IRIS2004 from flight IRIS2004_58, PANGAEA, https://doi.org/10.1594/PANGAEA.326937, 2005.

Haas, C.: Helicopter-borne sea ice thickness measurements during campaign IRIS2004 from flight IRIS2004_59, PANGAEA, https://doi.org/10.1594/PANGAEA.326938, 2005.

Haas, C.: Helicopter-borne sea ice thickness measurements during campaign IRIS2004 from flight IRIS2004_60, PANGAEA, https://doi.org/10.1594/PANGAEA.326939, 2005.

Haas, C.: Helicopter-borne sea ice thickness measurements during campaign IRIS2004 from flight IRIS2004_61, PANGAEA, https://doi.org/10.1594/PANGAEA.326940, 2005.

Haas, C.: Helicopter-borne sea ice thickness measurements during campaign IRIS2004 from flight IRIS2004_62, PANGAEA, https://doi.org/10.1594/PANGAEA.326941, 2005.

Haas, C.: Helicopter-borne sea ice thickness measurements during campaign IRIS2004 from flight IRIS2004_63, PANGAEA, https://doi.org/10.1594/PANGAEA.326942, 2005.

Haas, C.: Helicopter-borne sea ice thickness measurements during campaign IRIS2004 from flight IRIS2004_64, PANGAEA, https://doi.org/10.1594/PANGAEA.326943, 2005.

Haas, C.: Helicopter-borne sea ice thickness measurements during campaign IRIS2004 from flight IRIS2004_65, PANGAEA, https://doi.org/10.1594/PANGAEA.326944, 2005.
Haas, C.: Helicopter-borne sea ice thickness measurements during campaign IRIS2004 from flight IRIS2004_66, PANGAEA, https://doi.org/10.1594/PANGAEA.326945, 2005.

Haas, C.: Helicopter-borne sea ice thickness measurements during campaign IRIS2004 from flight IRIS2004_67, PANGAEA, https://doi.org/10.1594/PANGAEA.326946, 2005.

Haas, C.: Helicopter-borne sea ice thickness measurements during campaign IRIS2004 from flight IRIS2004_68, PANGAEA, https://doi.org/10.1594/PANGAEA.326947, 2005.

Haas, C.: Helicopter-borne sea ice thickness measurements during campaign IRIS2004 from flight IRIS2004_69, PANGAEA, https://doi.org/10.1594/PANGAEA.326948, 2005.

Haas, C.: Helicopter-borne sea ice thickness measurements during campaign IRIS2004 from flight IRIS2004_70, PANGAEA, https://doi.org/10.1594/PANGAEA.326949, 2005.

Haas, C.: Helicopter-borne sea ice thickness measurements during campaign IRIS2004 from flight IRIS2004_71, PANGAEA, https://doi.org/10.1594/PANGAEA.326950, 2005.

Haas, C.: Helicopter-borne sea ice thickness measurements during campaign IRIS2004 from flight IRIS2004_72, PANGAEA, https://doi.org/10.1594/PANGAEA.326951, 2005.

Haas, C.: Helicopter-borne sea ice thickness measurements during campaign IRIS2004 from flight IRIS2004_73, PANGAEA, https://doi.org/10.1594/PANGAEA.326952, 2005.

Haas, C.: Helicopter-borne sea ice thickness measurements during campaign IRIS2004 from flight IRIS2004_74, PANGAEA, https://doi.org/10.1594/PANGAEA.326953, 2005.

Haas, C.: Helicopter-borne sea ice thickness measurements during campaign IRIS2004 from flight IRIS2004_75, PANGAEA, https://doi.org/10.1594/PANGAEA.326954, 2005.

Haas, C.: Helicopter-borne sea ice thickness measurements during campaign IRIS2004 from flight IRIS2004_76, PANGAEA, https://doi.org/10.1594/PANGAEA.326955, 2005.

Haas, C.: Helicopter-borne sea ice thickness measurements during campaign IRIS2004 from flight IRIS2004_77, PANGAEA, https://doi.org/10.1594/PANGAEA.326956, 2005.

Haas, C.: Helicopter-borne sea ice thickness measurements during campaign IRIS2004 from flight IRIS2004_78, PANGAEA, https://doi.org/10.1594/PANGAEA.326957, 2005.

Haas, C.: Helicopter-borne sea ice thickness measurements during campaign IRIS2004 from flight IRIS2004_79, PANGAEA, https://doi.org/10.1594/PANGAEA.326958, 2005.

Haas, C.: Helicopter-borne sea ice thickness measurements during campaign IRIS2004 from flight IRIS2004_80, PANGAEA, https://doi.org/10.1594/PANGAEA.326959, 2005.

Haas, C.: Helicopter-borne sea ice thickness measurements during campaign IRIS2004 from flight IRIS2004_81, PANGAEA, https://doi.org/10.1594/PANGAEA.326960, 2005.

Haas, C.: Airborne electromagnetic sea ice thickness sounding in shallow, brackish water environments of the Caspian and Baltic Seas, Proceedings of OMAE2006 25th International Conference on Offshore Mechanics and Arctic Engineering, 4-9 June 2006, Hamburg, Germany, 6 pp., 2006.

Haas, C.: Helicopter-borne sea ice thickness measurements during campaign IRIS 2003 from flight HEM_IRIS03_06, Alfred Wegener Institute, Helmholtz Center for Polar and Marine Research, Bremerhaven, PANGAEA, https://doi.org/10.1594/PANGAEA.784165, 2012. 
Haas, C.: Helicopter-borne sea ice thickness measurements during campaign IRIS 2003 from flight HEM_IRIS03_07, Alfred Wegener Institute, Helmholtz Center for Polar and Marine Research, Bremerhaven, PANGAEA, https://doi.org/10.1594/PANGAEA.784166, 2012.

Haas, C.: Helicopter-borne sea ice thickness measurements during campaign IRIS 2003 from flight HEM_IRIS03_08. Alfred Wegener Institute, Helmholtz Center for Polar and Marine Research, Bremerhaven, PANGAEA, https://doi.org/10.1594/PANGAEA.784167, 2012.

Haas, C.: Helicopter-borne sea ice thickness measurements during campaign IRIS 2003 from flight HEM_IRIS03_09. Alfred Wegener Institute, Helmholtz Center for Polar and Marine Research, Bremerhaven, PANGAEA, https://doi.org/10.1594/PANGAEA.784168, 2012.

Haas, C.: Helicopter-borne sea ice thickness measurements during campaign IRIS 2003 from flight HEM_IRIS03_10. Alfred Wegener Institute, Helmholtz Center for Polar and Marine Research, Bremerhaven, PANGAEA, https://doi.org/10.1594/PANGAEA.784169, 2012.

Haas, C.: Sea ice thickness distribution, in: Sea ice, edited by: Thomas, D. N., Wiley-Blackwell, 664 pp., 2017.

Haas, C. and Hendricks, S.,: EM ice thickness measurements during 2005 IRIS field campaign, 7 to 18 March 2005, IRIS Deliverable $30,2005$.

Haas, C. and Hendricks, S.: Helicopter-borne sea ice thickness measurements during the POL-ICE field campaign in the Bay of Bothnia in March 2007 from flight HEM_POL-ICE07_01a, PANGAEA, https://doi.org/10.1594/PANGAEA.778263, 2012.

Haas, C. and Hendricks, S.: Helicopter-borne sea ice thickness measurements during the POL-ICE field campaign in the Bay of Bothnia in March 2007 from flight HEM_POL-ICE07_01b, PANGAEA, https://doi.org/10.1594/PANGAEA.778264, 2012.

Haas, C. and Hendricks, S.: Helicopter-borne sea ice thickness measurements during the POL-ICE field campaign in the Bay of Bothnia in March 2007 from flight HEM_POL-ICE07_01c, PANGAEA, https://doi.org/10.1594/PANGAEA.778265, 2012.

Haas, C. and Hendricks, S.: Helicopter-borne sea ice thickness measurements during the POL-ICE field campaign in the Bay of Bothnia in March 2007 from flight HEM_POL-ICE07_02a, PANGAEA, https://doi.org/10.1594/PANGAEA.778306, 2012.

Haas, C. and Hendricks, S.: Helicopter-borne sea ice thickness measurements during the POL-ICE field campaign in the Bay of Bothnia in March 2007 from flight HEM_POL-ICE07_02b, PANGAEA, https://doi.org/10.1594/PANGAEA.778267, 2012.

Haas, C. and Hendricks, S.: Helicopter-borne sea ice thickness measurements during the POL-ICE field campaign in the Bay of Bothnia in March 2007 from flight HEM_POL-ICE07_03, PANGAEA, https://doi.org/10.1594/PANGAEA.778268, 2012.

Haas, C. and Hendricks, S.: Helicopter-borne sea ice thickness measurements during the POL-ICE field campaign in the Bay of Bothnia in March 2007 from flight HEM_POL-ICE07_04, PANGAEA, https://doi.org/10.1594/PANGAEA.778269, 2012.

Haas, C. and Howell, S. E. L.: Ice thickness in the Northwest Passage, Geophys. Res. Lett., 42, 7673-7680, https://doi.org/10.1002/2015GL065704, 2015.

Haas, C., Gerland, S., Eicken, H., and Miller, H.: Comparison of sea-ice thickness measurements under summer and winter con- ditions in the Arctic using a small electromagnetic induction device, Geophysics, 62, 749-757, 1997.

Haas, C., Pfaffling, A., Hendricks, S., Rabenstein, L., Etienne, J. L., and Rigor, I.: Reduced ice thickness in Arctic Transpolar Drift favors rapid ice retreat, Geophys. Res. Lett., 35, L17501, https://doi.org/10.1029/2008GL034457, 2008.

Haas, C., Lobach, J., Hendricks, S., Rabenstein, L., and Pfaffling, A.: Helicopter-borne measurements of sea ice thickness, using a small and lightweight, digital EM system, J. Appl. Geophys., 67, 234-241, https://doi.org/10.1016/j.jappgeo.2008.05.005, 2009.

Haas, C., Hendricks, S., Eicken, H., and Herber A.: Synoptic airborne thickness surveys reveal state of Arctic sea ice cover, Geophys. Res. Lett., 37, L09501, https://doi.org/10.1029/2010GL042652, 2010.

Hendricks, S., von Saldern, C., and Haas, C.: Pol-Ice $2007 \mathrm{He}$ licopter EM Data Aquisition Report, Alfred Wegener Institute, 2007.

Jevrejeva, S., Drabkin, V. V., Kostjukov, J., Lebedev, A. A., Leppäranta, M., Mironov, Y. E. U., Schmelzer, N., and Sztobryn, M.: Baltic Sea ice seasons in the twentieth century, Clim. Res., 25, 217-227, 2004.

King, J., Spreen, G., Gerland, S., Haas, C., Hendricks, S., Kaleschke, L., and Wang, C.: Sea-ice thickness from field measurements in the northwestern Barents Sea, J. Geophys. Res.-Oceans, 122, 1497-1512, https://doi.org/10.1002/2016JC012199, 2017.

Koslowski, G. and Loewe, P.: The western Baltic Sea ice seasons in terms of mass related severity index 1879-1992, Tellus, 46A, 66-74, 1994.

Krumpen, T., Gerdes, R., Haas, C., Hendricks, S., Herber, A., Selyuzhenok, V., Smedsrud, L., and Spreen, G.: Recent summer sea ice thickness surveys in Fram Strait and associated ice volume fluxes, The Cryosphere, 10, 523-534, https://doi.org/10.5194/tc10-523-2016, 2016.

Kujala, P. and Montewka, J.: Final Report Summary - SAFEWIN (Safety of winter navigation in dynamic ice), available at: https://cordis.europa.eu/result/rcn/146133en.html, last access 25 September 2018.

Leppäranta, M.: The Drift of Sea Ice, Praxis Ltd, Chichester, UK, 2005.

Leppäranta, M. and Myrberg, K.: Physical Oceanography of the Baltic Sea, Springer-Praxis, Chichester, 378 pp., 2009.

Leppäranta, M. and Seinä, A.: Freezing, maximum annual ice thickness and break-up of ice on the Finnish coast during 1830-1984, Geophysica, 21, 87-104, 1985.

Löptien, U., Mårtensson, S., Meier, H. E. M., and Höglund, A.: Long-term characteristics of simulated ice deformation in the Baltic Sea (1962-2007), J. Geophys. Res.-Oceans, 118, 801815, 2013.

Meier, W. N., Hovelsrud, G. K., Van Oort, B. E. H., Key, J. R., Kovacs, K. M., Michel, C., Haas, C., Granskog, M. A., Gerland, S., Perovich, D. K., Makshtas, A., and Reist, J. D.: Arctic sea ice in transformation: a review of recent observed changes and impacts on biology and human activity, Rev. Geophys., 52, 185217, https://doi.org/10.1002/2013RG000431, 2014.

NOAA Climate Prediction Center: North Atlantic Oscillation, available at: http://www.cpc.ncep.noaa.gov/products/precip/ CWlink/pna/norm.nao.monthly.b5001.current.ascii, last access: 3 September 2018. 
Oikkonen, A., Haapala, J., Lensu, M., and Karvonen J.: Sea ice drift and deformation in the coastal boundary zone, Geophys. Res. Lett., 43, 10303-10310, 2016.

Palosuo, E.: Formation and Structure of Ice Ridges in the Baltic (Winter Navigation Research Board, Rep. No. 12), Board of Navigation, Helsinki, 1975.

Pärn, O. and Haapala, J.: Occurrence of synoptic flaw leads of sea ice in the Gulf of Finland, Boreal Environ. Res., 16, 71-78, 2011.

Pemberton, P., Löptien, U., Hordoir, R., Höglund, A., Schimanke, S., Axell, L., and Haapala, J.: Sea-ice evaluation of NEMONordic 1.0: a NEMO-LIM3.6-based ocean-sea-ice model setup for the North Sea and Baltic Sea, Geosci. Model Dev., 10, 31053123, https://doi.org/10.5194/gmd-10-3105-2017, 2017.

Pfaffling, A., Hendricks, S., and Martin, T.: Helicopter-borne sea ice thickness measurements during ARANDA campaign IRIS 2005 from flight HEM_IRIS05_01, PANGAEA, https://doi.org/10.1594/PANGAEA.784100, 2005.

Pfaffling, A., Hendricks, S., and Martin, T.: Helicopter-borne sea ice thickness measurements during ARANDA campaign IRIS 2005 from flight HEM_IRIS05_02, PANGAEA, https://doi.org/10.1594/PANGAEA.784101, 2005.

Pfaffling, A., Hendricks, S., and Martin, T.: Helicopter-borne sea ice thickness measurements during ARANDA campaign IRIS 2005 from flight HEM_IRIS05_03, PANGAEA, https://doi.org/10.1594/PANGAEA.784102, 2005.

Pfaffling, A., Hendricks, S., and Martin, T.: Helicopter-borne sea ice thickness measurements during ARANDA campaign IRIS 2005 from flight HEM_IRIS05_04a, PANGAEA, https://doi.org/10.1594/PANGAEA.784121, 2005.

Pfaffling, A., Hendricks, S., Martin, T.: Helicopter-borne sea ice thickness measurements during ARANDA campaign IRIS 2005 from flight HEM_ IRIS05_04b, PANGAEA, https://doi.org/10.1594/PANGAEA.784104, 2005.

Pfaffling, A., Hendricks, S., and Martin, T.: Helicopter-borne sea ice thickness measurements during ARANDA campaign IRIS 2005 from flight HEM_IRIS05_05a, PANGAEA, https://doi.org/10.1594/PANGAEA.784105, 2005.

Pfaffling, A., Hendricks, S., and Martin, T.: Helicopter-borne sea ice thickness measurements during ARANDA campaign IRIS 2005 from flight HEM_IRIS05_05b, PANGAEA, https://doi.org/10.1594/PANGAEA.784106, 2005.
Pfaffling, A., Hendricks, S., and Martin, T.: Helicopter-borne sea ice thickness measurements during ARANDA campaign IRIS 2005 from flight HEM_IRIS05_06a, PANGAEA, https://doi.org/10.1594/PANGAEA.784107, 2005.

Pfaffling, A., Hendricks, S., and Martin, T.: Helicopter-borne sea ice thickness measurements during ARANDA campaign IRIS 2005 from flight HEM_IRIS05_06b, PANGAEA, https://doi.org/10.1594/PANGAEA.784108, 2005.

Pfaffling, A., Hendricks, S., and Martin, T.: Helicopter-borne sea ice thickness measurements during ARANDA campaign IRIS 2005 from flight HEM_IRIS05_07, PANGAEA, https://doi.org/10.1594/PANGAEA.784109, 2005.

Su, J., Yang, B., Du, L., and Ji, S.: Monitoring Thin Ice Thickness by Upward-looking Sonar in Bohai Sea, Int. J. Offshore Polar., 23, 96-103, 2013.

Sugimoto, F., Tamura, T., Shimoda, H., Uto, S., Simizu, D., Tateyama, K., Hoshino, S., Ozeki, T., Fukamachi, Y., Ushio, S., and Ohshima, K. I.: Interannual variability in sea-ice thickness in the pack-ice zone off Lützow-Holm Bay, East Antarctica, Polar Sci., 10, 43-51, https://doi.org/10.1016/j.polar.2015.10.003, 2016.

Uotila, P., Vihma, T., and Haapala, J.: Atmospheric and oceanic conditions and the extremely low Bothnian Bay sea ice extent in 2014/2015, Geophys. Res. Lett., 42, 7740-7749, 2015.

Vihma, T. and Haapala, J.: Geophysics of sea ice in the Baltic Sea: A review, Prog. Oceanogr. 80, 129-148, 2009.

Vihma, T., Cheng, B., Uotila, P., Lixin, W., and Ting, Q.: Linkages between Arctic sea ice cover, large-scale atmospheric circulation, and weather and ice conditions in the Gulf of Bothnia, Baltic Sea, Adv. Polar Sci., 25, 289-299, 2014.

Weissling, B. P., Lewis, M. J., and Ackley, S. F.: Seaice thickness and mass at Ice Station Belgica, Bellingshausen Sea, Antarctica, Deep-Sea Res. Pt. II, 58, 1112-1124, https://doi.org/10.1016/j.dsr2.2010.10.032, 2011.

Worby, A. P., Geiger, C. A., Paget, M. J., Van Woert, M. L., Ackley, S. F., and DeLiberty T. L.: Thickness distribution of Antarctic sea ice, J. Geophys. Res., 113, C05S92, https://doi.org/10.1029/2007JC004254, 2008. 